\title{
Boşanmanın Tarafları Ademler ve Havvalar: Bir Duruşma Gözlem Araştırması ${ }^{1}$
}

\author{
DOI: $10.26466 /$ opus.656948
}

\author{
* \\ Hatice Nuhoğlu* - Filiz Demiröz ${ }^{* *}$ \\ * Dr. Öğr. Üyesi Kastamonu Üni., Sağlık Bilimleri Fak., Sosyal Hizmet Böl., Kastamonu, Türkiye \\ E-Posta: hatice.nuhoglu@gmail.com \\ ORCID: 0000-0003-1466-6914 \\ **Dr. Öğr. Üyesi Hacettepe Üni., İ.İ.B.F., Sosyal Hizmet Böl., Ankara, Türkiye \\ Öz \\ E-Posta: filiz.demiroz@gmail.comＯRCID: $\underline{0000-0001-8606-7350}$
}

Bu çalı̧̧ma, bugüne kadar anlatılmayan, duruşma salonlarının ardında kalan boşanma hikâyelerini gün yüzüne çıkarmak üzere hazırlanmıştır. Bu nedenle boşanma aşamasındaki taraflar betimlenerek duruşma salonundaki temsilleri ortaya konulmuştur. Bu amaç doğrultusunda araştırmanın yöntemi nicel yöntem olarak tasarlanmıştır. Veriler nicel araştırma veri toplama tekniklerinden yapılandırılmış (denetimli) gözlem tekniği ile elde edilmiştir. Veri toplama sürecinde Ankara Sihhiye Adliyesi'nde yer alan 11 aile mahkemesinde toplam 200 duruş,ma gözlemlenmiş, duruşma gözlem sürecinden elde edilen veriler SPSS 23.0 for Windows programında analiz edilmiştir. Araştırmada tanımlayıcı istatistikler; kategorik değiş̧kenler için frekans (\%), sürekli değiş̧kenler için ortalama \pm standart sapma ve ortanca (minimum-maksimum) olarak verilmiştir. Yapılan analiz sonucunda boşanmanın kadın ve erkek açısından ruhsal, ekonomik, yasal ve sosyal boyutlarda farklı bir yapıya sahip olduğu ortaya çıkmıştır. Elde edilen bir diğer önemli bilgi, evlilik ve boşanma sürecinde yaşanan çatışmaların kesişimsel olduğudur. Ayrıca çatışma konularının müstakil olmadıkları sonucuna ulaşılmıştır. Çatışma konuları genellikle birbirleri ile ilişkili ya da birbirlerini tetikleyici özelliğe sahiptir.

Anahtar Kelimeler: Boşanma, Duruşma Gözlemi, Aile Mahkemesi, Boşanmanın Tarafları

\footnotetext{
${ }^{1}$ Bu çalışma yazarın doktora tezinden üretilmiştir. Nuhoğlu, H. (2019). Boşanma Sürecinde Çatışma Deneyimlerinin Stratejik Aile Terapisi Temelinde Analizi Bir Karma Yöntem Araştırması. Doktora Tezi. Hacettepe Üniversitesi. Sosyal Bilimler Enstitüsü. Sosyal Hizmet Anabilim Dalı. Ankara.
} 


\title{
Divorce Parties Adam And Eve: A Trial Observation Research
}

\begin{abstract}
This study has been prepared to reveal the divorce stories behind the hearing room that have not been brung to light until today. For this reason, the parties in the divorce stage and their representation in the courtroom were put forward. For this purpose, the research method was designed as a quantitative method. The data were obtained through structured (supervised) observation technique from quantitative research data collection techniques. Structured (controlled) observation technique was used in the quantitative dimension of the research; a total of 200 trials in 11 different family courts in Ankara Sihhiye Courthouse were observed. Quantitative data obtained from the observation process were firstly analyzed with SPSS 23.0 for Windows Program. In this research, descriptive statistics were given as; frequency $(\%)$ for categorical variables, mean \pm standard deviation for continuous variables and median (minimum-maximum). As a result of the analysis, it was revealed that divorce has a different structure for women and men in terms of mental, economic, legal and social dimensions. Another important information obtained is that the conflicts in the process of marriage and divorce are intersectional. In addition, it was concluded that conflict issues are not detached. Conflict issues are generally related or triggering each other.
\end{abstract}

Keywords: Divorce, Trial Observation, Family Court, Divorce Parties 


\section{Giriş}

Boşanma, ilk yazılı belgelerden (Kültepe Tabletleri, M.Ö \pm 1975- 1723) günümüze kadar olan süreçte insanlık tarihinin önemli yaşam olaylarından birisi olmuştur. Dönemsel koşullar ve siyasi, ekonomik ve toplumsal olaylarla birlikte birçok kez yeniden düzenlemeye gidilmiş ve günümüzdeki görünümüne ulaşmıştır.

Modern boşanma biçimlerinin kökleri, 200 yıldan fazla bir süreye, evliliğin aşka ve karşılıklı ilişkiye dayalı olması gerektiğine ilişkin tarihsel olarak yeni bir düşüncenin keşfine dayanmaktadır (Coontz, 2006). Toplumların çeşitli dönemlerinde dini inanç ve yaptırımlar boşanmaya yaklaşımda etkili olmuş, daha sonraları yasal düzenlemeler ya dini düzenlemeleri bütünleyici ya da onları aşarak belirleyici bir nitelik kazanmıştır (Arıkan, 1996). Dolayısıyla boşanma insanlığın bir gereksinim olarak ürettiği evlilikle birlikte kendisini var eden bir kurum olarak varlığını sürdürmüş ve halen sürdürmektedir. Boşanma her ne kadar evliliğin doğal bir sonucu olarak ortaya çıksa da boşanma, toplumsal kabul açısından evlilik kadar başarılı bir konuma gelememiştir. Boşanma günümüzde halen toplum tarafından zor adapte olunan bir süreç olarak karşımıza çıkmaktadır.

Çünkü boşanma, içinde yer alanları bir dizi zorluğa yöneltmektedir. Boşananlar, başarısız olduklarına, sevgi alma ve verme becerilerine, yalnızlık hissine, boşanmaya eşlik eden damgalanmaya, arkadaşların ve akrabaların tepkisine, ayrılarak doğru şeyi yapıp yapmadıklarına ve kendi başlarına yapıp yapamayacaklarına dair duygusal endişelerle yüzleşirler (Zastrow ve Kirst-Ashman, 2015). Mutsuz çiftler; dinsel kısıtlamalar, çocukların sorumlulukları, maddi kaygılar, boşanmanın olumsuz sonuçları ve evli kalmaya yönelik baskıları göz ardı edemezler. Tüm bu olumsuz sonuçlara rağmen, mutsuz evliliklerini sonlandırma düşüncesine sahip olan çiftler en sonunda ayrılmaya ve boşanmaya karar verirler ve bunu ifade ederler (Clarke-Stewart ve Brentano, 2006).

Çiftler boşanmaya karar verdiklerinde bu kararlarını yasal bir zemine taşımaları gerekir. Salts ve Smith (2013), boşanma aşamasında yasal boşanma süreçlerinden bahsetmektedir. Onlara göre, yasal boşanma, evliliklerini yasal olarak sonlandırmak amacıyla tarafların beraber ya da ayrı ayrı dava açmalarını içerir. 
Bu çalışma boşanmanın yasal boyutunu ele almakta ve boşanmak üzere yasal süreçleri başlatan tarafların içinde bulundukları durumu duruşma gözlem yöntemi ile betimleme amacındadır. Dolayısıyla sonraki bölümde boşanmanın yasal boyutu ve duruşmaların aleniyeti üzerinden dava izleme ve duruşma gözlemi ele alınmıştır.

\section{Boşanmanın Yasal Boyutu}

Yasa, "geçimsizlik" nedeni ile bozulan karı-koca ilişkilerini, aile dışından, daha objektif ve uzman olan bir dış kurumun değerlendirmesini gerekli görmüş, iletişimleri kopan karı-koca ve çocukların boşanma ile ortaya çıkacak haklarını da korumuştur (Özgüven, 2010). Çünkü Aile Hukukunda evlenme, bir medeni hukuk sözleşmesidir. Evlenme sözleşmesinden bazı haklar ve yükümlülükler doğar (Akıntürk ve Ateş, 2016).

Medeni Kanun, evlenmeyle eşler arasında evlilik birliğinin kurulmuş olduğunu belirtir. Eşler, bu birliğin mutluluğunu elbirliğiyle sağlamak ve çocuklarm bakımına, eğitim ve gözetimine beraberce özen göstermekle yükümlüdürler. Eşler, birlikte yaşamak, birbirine sadık kalmak ve yardımoı olmak zorundadır (TMK, m.185). Birliği eşler beraberce yönetirler ve giderlerine güçleri oranında emek ve mal varliklar ile katılırlar (TMK, m.186). Eşlerden her biri, ortak yaşamın devamı süresince ailenin sürekli ihtiyaçlan için evlilik birliğini temsil eder (TMK, m.188).

Aile bireylerinin birbirleri ile ilişkilerinin koşullarına veya sonuçlarına ilişkin kanuni düzenlemeler çoğunlukla emredici kurallarla düzenlenmiştir (Zevkliler ve diğerleri, 1999; akt: Karacan, 2008). Devlet ailevi ilişkilere sadece kamu düzenini sağlama amaciyla müdahale etmektedir (Uçar, 2003; akt: Karacan, 2008). Dolayısıyla boşanmanın yasal boyutu devlet kontrolü altında gerçekleşmektedir. Boşanma davaları kamu düzenini ilgilendirdiğinden devlet, Hukuk Muhakemeleri Kanunu'nun öngördüğü kurallar dışında 4721 sayılı Türk Medeni Kanun'unda da gerek boşanma ve gerekse ayrılık davası yönünden özel kurallar getirmiştir (Gençcan, 2016).

Bu özel kurallar boşanmanın yasal boyutu devreye girdiğinde, bir zamanlar karşılıklı ilişkinin devam etmesinden kaynaklı olarak sorun kabul edilmeyen "şeyler" in, evlilikte önemsenmeyen-üzerinde durulmayan ya da üstü kapatılan çatışma konularını, yastık altındaki hazinelere dönüşmesine ve boşanma savaşının birer malzemesi haline gelerek boşanma sürecinin gündemini oluşturmasına neden olur. Artık bunlar, savaşın kazanını belirleyecek 
cephaneliklerdir. Silahların çekildiği bu noktada taraflar, dilekçelere dökülen sözler ve duruşmalarda dile gelen tanıkların beyanları ile yüzleşmek durumundadır. Boşanma olgusu yasal boyuta gelindiğinde mahkeme sürecinde gerçekleşen olaylarla birlikte başka türden bir ivme kazanmış olur.

Boşanmanın yasal boyutu bu nedenle boşanmanın diğer boyutlarını harekete geçirici bir etkiye sahiptir. Boşanma yasal bir dava konusu haline geldiğinde ekonomik, toplumsal ve ruhsal boyutları birbirlerinden ayırmak zorlaşır.

\section{Duruşmaların Aleniyeti ve Dava İzleme}

Boşanma, insan hayatındaki üç önemli eşikten (doğum, evlilik ve ölüm) biri olan evliliğin bir diğer yüzüdür. Ancak boşanma, insanlar için madalyonun öteki yüzünü temsil eder; yolunda giden bir evliliğin, gözden uzak tutulması gereken yüzünü. Evliliğin diğer yüzü ile karşılaşan ve boşanma kararı alan çiftler, yollarını ayırabilmek için "şimdi ve burada", duruşma salonunda, bu deneyimlerini "yabanc1" insanların gözü önünde, mahkeme huzurunda ispat etmek zorundadır. Boşanma davalarının görüldüğü aile mahkemelerinde duruşmalar yasa gereği aleni şekilde yapılır. Aleniyet ilkesi yargılamaya hakim olan ilkelerdendir. Aynı zamanda adil yargılanmanin bir unsurudur.

Kural olarak duruşmalar herkese açık ve aleni olsalar dahi, sonuç olarak duruşmalar kapıları kapalı bir duruşma salonunda gerçekleşmektedir ve yalnızca duruşma salonuna giren kişiler duruşmada neler olup bittiğini görebilmektedir. Duruşma salonunda birtakım izleyicinin bulunduğu durumlarda dahi, duruşmada fiilen bulunmayanlar ancak duruşma tutanaklarından veya bu tutanaklara dayanılarak yazılan haberlerden gelişmeleri takip edebilecektir. Bunlar da büyük ölçüde teknik ve hukuki metinler olacaktır. Oysa ki duruşma salonunda yaşananlar yalnızca duruşma tutanağına yansıyanlardan ibaret değildir (Yavan, 2017). Bu nedenle duruşma gözlem araştırmaları oldukça önemlidir. Bu aynı zamanda adil yargılanma ve yargılamanın aleniyet ilkesinin bir gereğidir.

Adil yargılanma hakkı ve duruşmaların aleniyeti ilkesi başta Evrensel İnsan Hakları Beyannamesi 10. maddesi ve Uluslararası Medeni ve Siyasal Haklar Sözleşmesi'nin 14. maddesi olmak üzere, bir dizi uluslararası insan hakları sözleşmesinde tanımlanmaktadır. BM İnsan Hakları Savunucularının 
Korunması Bildirgesi Madde 9(3) dava izlemeyi bir hak olarak şu şekilde tanımlamaktadır: "Ulusal yasalar ile uygulanabilir uluslararası yükümlülük ve taahhütlerin uygunluğu üzerine kanaat oluşturma amactyla, duruşmalarda, kovuşturmalarda ve kamu davalarında hazır bulunma." (Çiftçioğlu, 2017). Yasayla kurulmuş, bağımsız ve tarafsız mahkeme, hakkaniyete uygun yargılama ve makul süre içinde aleni yargılamayı AïHS adil yargılama hakkının temel kriterleri olarak belirler. Bu kriterler bağlaminda mahkemeye erişim, masumiyet karinesi, susma hakkı, silahların eşitliği gibi pek çok faktörün eş zamanlı göz önüne alınmasını gerektirmektedir (Blackman, 2017).

Aleniyet ilkesi ise, yargılamanın tarafı olmayan üçüncü kişilerin, yargılamayı izleyebilmesi ve yargilamanın sonucunda verilen hükmü öğrenebilmesi anlamına gelir (Kurt Konca, 2014). Aile mahkemelerinde duruşma gözlemini içeren bu çalışma ile önemle üzerinde durulması gereken konu, duruşma salonlarında dışarıdan gözlem yapma amaçlı dava takip etmenin yaygın olmamasıdır. Oysa bugün dava izleme, küresel ölçekte yaygın ve kabul edilen bir pratik haline gelirken (Çiftçioğlu, 2017), uluslararası teamül hukukunun da bir parçası olarak kabul edilmektedir.

Ancak dava izleme denilince yaygın olarak insan haklarından doğan davaların izlenmesi gündeme gelmektedir. Aile hukukundan doğan davalara bakan aile mahkemelerinde dava izleme ise henüz yeteri kadar yaygın değildir. Bu nedenle boşanma davalarının izlenmesine ilişkin araştırmalar yok denecek kadar azdır. Bu çalışma boşanma davalarına ilişkin duruşma gözlemi ile elde edilen verilerle hazırlandığından duruşma gözlemlerine ilişkin öncü çalışmalar arasında yer almaktadır. Dolayısıyla bu çalışma boşanma sürecinin yasal boyutuna odaklanarak duruşma salonunda tarafların içinde bulundukları durumu betimlemeyi ve tarafların duruşma salonunda temsillerini ortaya koymayı amaçlamaktadır.

\section{Yöntem}

Çalışmanın bu bölümünde, araştırmanın amacı ile uyumlu olacak şekilde belirlenen araştırmanın modeli, amacı, veri toplama araçları, veri toplama süreci ve analiz hakkında ayrıntılı bilgilere yer verilmiştir. 


\section{Araştırmanın Modeli}

Araştırmanın modeli nicel yöntem olarak belirlenmiştir. Araştırmanın nicel boyutu, genel tarama modellerinden tekil tarama modelinde kurgulanmıştır.

\section{Araștırmanın Amacı}

Boşanma sürecindeki tarafların içinde bulundukları durumu duruşma salonu deneyimleri üzerinden duruşma gözlem yöntemi ile betimlemek amacıyla hazırlanan bu çalışmada mahkeme sürecine ilişkin aşağıda yer alan sorulara yanıt aranmaya çalışılmıştır.

1. Boşanmanın taraflarının sosyo-demografik özellikleri nelerdir?

- Cinsiyet

- Davaci-davalı olma durumları

- Avukatla temsil durumu

- Aile yaşam döngüsünde ailenin konumu

- Müşterek çocuk

- İkamet ettikleri yer

- Ayrilma biçimleri

2. Duruşma salonuna ilişkin bilgiler nelerdir?

- Duruşma salonunda bulunanlar

- Duruşma salonunda çatışma yaşanma durumu

3. Davaya ilişkin bilgiler nelerdir?

- Davanin türü

- Davanin hangi aşamada olduğu

- Davanin karara bağlanması

- Velayetin verilme durumu

4. Çatışma konularına ilişkin bilgiler nelerdir?

- Evlilik sürecindeki çatışma konuları

- Boşanma sürecindeki çatışma konuları

\section{Veri Toplama Araçları}

$\mathrm{Bu}$ araştırmada nicel araştırma veri toplama tekniklerinden yapılandırılmış (denetimli) gözlem tekniği kullanılmıştır. Duruşma gözlemlerine başlamadan önce duruşma gözlem formu oluşturulmuş ve 10 adet örnek duruşma 
gözleminden sonra gözlem formu yeniden gözden geçirilmiş ve son şekli verilmiştir. Takip edilen duruşmalar bu gözlem formu çerçevesinde gözlemlenmiştir.

Duruşma gözlemi “Tematik dava izleme yöntemi" kullanılarak gerçekleştirilmiştir. Tematik dava izleme yöntemi, ağır insan hakkı ihlalleri ve cezasızlık sorunu, savaş suçları, kadına yönelik erkek şiddeti gibi belirli temalara ilişkin davalara odaklanarak, bu alanlara yönelik spesifik ve daha derinlemesine değerlendirme yapmayı amaçlayan izlemeler şeklinde tanımlanabilir. $\mathrm{Bu}$ yöntem ile yapılan dava izleme faaliyeti genellikle belirli bir bölgede, belirli bir tema etrafında şekillenen davaların düzenli olarak izlenmesi ve ilgili alana özgü sorunların açığa çıkartılarak bu yönde kurumsal ve yargısal reformların teşvik edilmesi hedeflenir (Yavan, 2017).

$\mathrm{Bu}$ çalışmada ise tema, boşanma davaları olarak belirlenmiş ve boşanma davalarında duruşma süreçlerine ilişkin gözlem gerçekleştirilirken boşanma aşamasındaki tarafların duruşma deneyimlerinin ve hukukun uygulanması sürecinin ortaya konması hedeflenmiştir.

\section{Veri Toplama Süreci}

Ankara Sihhiye'de yer alan Adalet Sarayı'nda bulunan 11 adet aile mahkemesinde toplam 200 duruşma takip edilmiştir. Duruşma takibi noktasında kota örneklem seçim tekniği kullanılmıştır. Kota örneklem seçim tekniği, önce örnekleme girecek olanlarm sahip olması gereken özelliklerin saptandığl, sonra her özelliğe sahip kaç kişinin seçileceğine ilişkin kotalarn oluşturulduğu ve bu kota sayısı kadar birimin gelişigüzel örneklem seçim tekniğiyle seçildiği örnekleme tekniğidir (Sencer ve Sencer, 1978).

Aile Mahkemelerinde açılan dava sayısına ulaşmak mümkün olmadığından evrendeki kişi sayısının bilinmediği durumlarda kullanılan örneklem hesaplama yöntemine (n=t(kare).p.q/d(kare)) başvurulmuştur. Buna göre TÜİK (2016) yıllık boşanma ve evlilik oranlarına bakılmış ve boşanmanın evliliğe göre yüzdesi hesaplanarak boşanmanın görülme sıklığı elde edilmiştir. Güven aralığı 0,05 olarak belirlenmiş ve örneklem sayısı 187 kişi olarak elde edilmiştir.

Her bir aile mahkemesine dosyalar eşit sayıda dağıtıldığından dolayı 11 aile mahkemesinde duruşma gözlemi yapılmasına karar verilmiştir. 200 du- 
ruşma gözleminden sonra gözlem açısından yeterli doyum sağlandığına karar verilmiş ve veri toplama süreci sonlandırılmıştır. Aşağıda yer alan Tablo 1 'de gözlemlenen mahkemelere ait duruşma sayılarına yer verilmiştir.

Tablo 1. Takip Edilen Duruşma Sayılarının Mahkemelere Göre Dağılımı

\begin{tabular}{lll}
\hline Aile Mahkemesi & N & \% \\
\hline 1 Aile Mahkemesi & 18 & 9,0 \\
\hline 2 Aile Mahkemesi & 18 & 9,0 \\
\hline 3 Aile Mahkemesi & 16 & 8,0 \\
\hline 4 Aile Mahkemesi & 18 & 9,0 \\
\hline 5 Aile Mahkemesi & 18 & 9,0 \\
\hline 6 Aile Mahkemesi & 22 & 11,0 \\
\hline 7 Aile Mahkemesi & 20 & 10,0 \\
\hline 8 Aile Mahkemesi & 18 & 9,0 \\
\hline 9 Aile Mahkemesi & 18 & 9,0 \\
\hline 10 Aile Mahkemesi & 17 & 8,5 \\
\hline 11 Aile Mahkemesi & 17 & 8,5 \\
\hline Toplam & 200 & 100,0 \\
\hline
\end{tabular}

Duruşma gözlemine başlamadan önce 11 aile mahkemesinde görevli hakimlerle tek tek görüşme gerçekleştirilmiş ve araştırma konusunda kendilerine bilgi verilerek duruşma gözlemi için her bir aile mahkemesi hakiminden ayrı ayrı izin alınmıştır. Her bir aile mahkemesindeki hakim duruşma gözlemine ilişkin olumlu tepki vermiştir. Ayrıca Hacettepe Üniversitesi'nden gerekli etik kurul izni alınmış ve bu izin hakimlerle paylaşılmıştır. İzinler alındıktan sonra 12.05.2017-21.06.2017 tarihleri arasında 10 adet duruşma gözlemi yapılmış ve gözlem formunda düzenlemeye gidilmiştir. Temmuz ve Ağustos 2017 aylarında adli tatil olmasından dolayı gözlemlere ara verilmiş, adli tatilin sona ermesinden sonra yeni dönemde duruşma gözlemlerine başlanmıştır. Sonuç olarak veriler 05.09.2017-30.01.2018 tarihleri arasında toplanmıştır.

Duruşma gözlemi sırasında "nesnel olmak" ilkesine bağlı kalınmış ve duruşmalar gerçekleştiği şekliyle betimlenmiştir. Yasaya göre mahkemede kayıt almak (ses kayıt cihazı kullanmak) yasak olduğu için (m.153) duruşmalardan elde edilen veriler araştırmacı tarafından kalem kağıt aracılığıyla kayıt altına alınmış daha sonra gözlem formuna aktarılmıştır. 


\section{Verilerin Analizi}

Duruşma gözlem sürecinden elde edilen nicel veriler öncelikle "SPSS 23.0 for Windows" programına aktarılmış, daha sonra aktarılan veriler yine aynı programda analiz edilmiştir. Araştırmada tanımlayıc istatistikler; kategorik değişkenler için frekans (\%), sürekli değişkenler için ortalama \pm standart sapma ve ortanca (minimum-maksimum) olarak verilmiştir.

Veriler araştırmanın bulgular kısmında tablolar şeklinde gösterilmiştir. Buna ek olarak ayrıca duruşmalara ilişkin genel bir görüş elde etmek amacıyla tanıkların ve tarafların beyanlarına ve duruşma sürecinde yaşanan olaylara yer verilmiştir. Beyanlar herhangi bir değişikliğe gidilmeden kişilerin ağzından çıktığı şekliyle aktarılmıştır. Bu aktarımlar “..." şeklinde verilmiş ve ayırt edici olması bakımından aktarımların başında araştırmacı tarafından verilmiş olan dosya numaraları eklenmiştir.

\section{Bulgular}

Aşağıda yer alan bölümde bir zamanlar kendi veya yakınlarının kararları ile severek ya da sevmeden evlenen, evliliklerinin üzerinden bir yıl bile geçmemiş ya da bir çeyrek asır geçmiş 200 çiftin boşanma hikâyesi, 4 temel alt başlıkta toplanmıştır: (1) Boşanmanın taraflarına ilişkin veriler (2) Davaya ilişkin veriler (3) Duruşmalara ilişkin veriler (4) Çatışma konularına ilişkin veriler.

Evlilik ilişkisi içinde çift ya da karı-koca olarak tanımlanan bireyler, boşanma aşamasına geçtiklerinde dava ilişkisi içinde ele alınırlar ve taraf olarak tanımlanırlar. Dolayısıyla çalışmanın bundan sonraki bölümünde çiftleri tanımlamada, "çift" yerine "taraf" ifadesi kullanılmıştır.

\section{Taraflara İlişkin Demografik Bulgular}

Taraflara ilişkin demografik bulgular bölümünde davası görülen taraflar, sosyo-demografik bulgular açıdından incelenmiştir. Buna göre, davacı ve davalının cinsiyet dağılımı, avukatla temsil durumu, aile yaşam döngüsünde ailenin konumu, müşterek çocuğa sahip olma durumu, müşterek çocuk sayısı, boşanma sürecinde ikamet ettikleri yer ve en son ayrılma biçimleri üzerinde durulmuştur. 
Tablo 2. Davacı ve Davalının Cinsiyet Dă̆ılımı

\begin{tabular}{lllll}
\hline \multirow{2}{*}{ Cinsiyet } & Davacı & \multicolumn{3}{l}{ Davalı } \\
\cline { 2 - 5 } & $\mathrm{N}$ & $\%$ & $\mathrm{~N}$ & $\%$ \\
\hline Kadın & 137 & 68,5 & 63 & 31,5 \\
\hline Erkek & 63 & 31,5 & 137 & 68,5 \\
\hline Toplam & 200 & 100,0 & 200 & 100,0 \\
\hline
\end{tabular}

Tablo 2'ye göre, boşanma davalarında kadınların \%68,5'i, erkeklerin $\% 31,5^{\prime} \mathrm{i}$ davacı olurken kadınların \%31,5'i, erkeklerin \%68,5'i davalı konumundadır.

Çoğunlukla kadınların davayı açan taraf olması önemlidir. Ancak burada ayırım yapılması gereken önemli bir noktanın altını çizmekte fayda vardır. Tarafların boşanma davası açma durumu ile boşanmayı isteme durumu aynı şeyi ifade etmemektedir. Boşanmayı kabul etmeme başka bir noktadadır. Bu konu boşanma sürecinde çatışma konuları bölümünde ayrıntılı bir şekilde ele alınmıştır.

Ülkemizde 1966 yılına kadar erkek davacılar çoğunlukta olduğu halde kadın davacı sayısı giderek artmıştır. Yakın zamanlara kadar istatistiksel veriler, birçok ülkede erkek davacıların daha fazla olduğunu gösterdiği halde son yıllarda bunun tersi bir oranın ortaya çıktığı görülmektedir (Işıktaç ve Koloş, 2017). Asliye hukuk mahkemelerinde yargilama sürecine ilişkin bir araştırmada da kadın ve erkeklerin davacı olarak yer aldığ dava tiplerine yer verilmiştir. Buna göre, kadın ve erkekler asliye hukuk mahkemelerini en çok aile ile ilgili konularda kullanmaktadırlar. Kadınların ise bu amaçla mahkemelerden erkeklere göre daha çok yararlandığı gözlemlenmiştir. Tek başına boşanma davalarına bakıldığında, bu davaların \%65'inde kadınların davacı olduğu bulgusu yer almaktadır (Elveriş ve diğerleri, 2009). Bu bulgu, araştırmanin bulguları ile uyumludur.

Son yıllarda eşler arasında daha çok kadınların boşanma davası açması; kadınların gün geçtikçe özellikle genç nüfusta ekonomik bağımsızlık kazanmaları, nafaka hakkının sağlanması, değişen evlilik ve boşanma algısı, kadının güçlenmesi gibi pek çok farklı boyutlarda ele alınabilir. Işıktaç ve Koloş (2017)'a göre; yeni modern kadın, her ne pahasına olursa olsun evli kalmaya razı olmamaktadır. Bunun, bir diğer evlenmeyi olanaklı görmesi veya evli ol- 
maksızın da ekonomik ve toplumsal statüsünü sürdürebilmesi gibi olanaklarla orantılı olduğu da görülmektedir. Ancak, "her zillete katlantp, ayrllmamak kadın için bir fazilet" olmaktan çıkmıştır.

Kadınların özellikle boşanma davalarında daha çok dava açan taraf olması, kadının doğumundan ölümüne kadar geçen zaman içerisinde geçirdiği en belirleyici deneyimin evlilik olması ile ilişkilendirilebilir. Evliliğe göre konumu, kadını tanımlayan bir ölçektir. Halbuki böyle bir ölçek erkekler için belirleyici değildir. Erkek geç bir yaşa kadar evlenmemiş olsa bile onun için "eode kalmış" sıfatı pek kullanılmaz, boşanmış erkeklere "dul" denildiği çok az görülür. "Metres", "kapatma" ve "kuma" sözcükleriyse tümüyle kadınlar için kullanılan sıfatlardır (Soysal, 2016). Dolayısıyla evliliğin kadının yaşamındaki bu önemli konumu, onu boşanma ile karşı karşıya gelindiğinde de birinci aktör haline getirmektedir.

Davacı ve davalı olma durumlarını yorumlamak ayrıca boşanmanın birey üzerinde yarattığı etkisine de vurgu yaptığ için önemlidir. Boşanma arabuluculuğu araştırmacıları, her iki taraf tarafından veya tek taraflı olarak başlatılan boşanmalar arasındaki farkları incelemişlerdir (Emery 1995; Bickerdike and Littlefield 2000; akt: Baitar ve diğerleri, 2012). Belirli bir biçimde, dava sürecini başlatmayanların boşanma kararıyla boğulma ihtimalinin daha yüksek olduğu ve eski eşe karşı çözülmemiş yoğun bağlanma duyguları yaşadığı görülmüştür. Buna karşılık, dava sürecini başlatanların boşanmaya uyum sağlamak için daha fazla zamanları olduğu ve dolayısıyla ilişkinin değişen sınırlarına uyum sağlama konusunda daha az zorluk yaşadıkları bulunmuştur. (Emery 1995; Kruk 1998; akt: Baitar ve diğerleri, 2012).

Bu bilgiden hareketle ülkemizde boşanma sürecindeki kadın cinayetleri düşünüldügüunde daha çok kadınların boşanma davası açması ve erkeklerin dava sürecini başlatan taraf olmamasının boşanma kararıyla baş etmede sorun yaşadıkları yorumunu düşündürmektedir. Boşanma kararını kendisi almayan erkeğin bu karara katılmakta ve eski eşten kopma noktasında zorlanmakta olduğu söylenebilir. Bu durum ayrıca boşanma sürecindeki çatışma konuları bölümünde ayrıntılı olarak incelenmiştir. 
Tablo 3. Avukatla Temsil: Davacı ve Davalının Cinsiyetleri ile Avukatlarnın Olma Durumu

\begin{tabular}{|c|c|c|c|c|c|c|}
\hline \multicolumn{7}{|c|}{ Davacının Avukatının Olma Durumu } \\
\hline Davacı Cinsiyeti & Evet & $\%$ & Hayır & $\%$ & Toplam & $\%$ \\
\hline Kadın & 89 & 65,0 & 48 & 35,0 & 137 & 100,0 \\
\hline Erkek & 45 & 71,4 & 18 & 28,6 & 63 & 100,0 \\
\hline Toplam & 134 & & 66 & & 200 & 100,0 \\
\hline \multicolumn{7}{|c|}{ Davalının Avukatının Olma Durumu } \\
\hline Davalı Cinsiyeti & Evet & $\%$ & Hayır & $\%$ & Toplam & $\%$ \\
\hline Kadın & 40 & 63,5 & 23 & 36,5 & 63 & 100,0 \\
\hline Erkek & 65 & 47,4 & 72 & 52,5 & 137 & 100,0 \\
\hline Toplam & 105 & & 95 & & 200 & 100,0 \\
\hline
\end{tabular}

Tablo 3'e göre, kadınların ve erkeklerin temsil edilme durumu birbirinden farklıdır. Aynı zamanda bu farklılık tarafların davacı ya da davalı olma durumlarına göre de değişmektedir. Buna göre, kadınların davacı olduklarında avukatla temsil edilme durumu \%65 iken davalı olma durumların \%63,5'tir. Erkeklerin ise davacı olduklarında avukatla temsil edilme durumu \%71,4 iken davalı olduklarında \%47,4'tür. Avukatla temsil edilmek hak savunuculuğu açısından oldukça önemlidir.

Araştırmanın bulguları kadınların ve erkeklerin yarısından fazlasının avukatla temsil edildiğini ortaya koymaktadır. Ancak araştırma duruşma gözlemine dayalı olduğundan hali hazırda dava açan tarafları içermektedir. Oysa duruşma salonu dışında halen dava açma hakkını kullanmayan kişilerin varlığından da söz etmek gerekir.

Türkiye' de avukat olmaksızın kendi davasını yürütmeye çalışan azımsanmayacak sayıda kişi bulunmaktadır. Nitekim Adalet Barometresi araştırması avukattan yararlanma oranının düşük olduğunu, halkın dörtte üçünün avukatlık hizmetini pahalı bulduğunu göstermektedir. Ücretsiz avukatlık hizmetinden yararlananların oranı \%10'u aşmamaktadır. Avukatlık hizmetinden yararlanamayanların adalete ulaşabilmeleri açısından bilgi edinebilmeleri çok önemlidir. İnsan Hakları Avrupa Mahkemesi (İHAM) kararlarında belirtildiği gibi, devletin maddi olanakları yetersiz kişiler bakımından ücretsiz avukat yardımı sağlamadığı durumlarda, mahkemeye ulaşma hakkını güvence altına almak için başka yöntemleri kullanması gerekmektedir. En etkili yöntem, davayı kişinin kendi başına yürütebileceği basitlikte bir sistem kurmaktır. (İnceoğlu, 2009). 
Duruşma gözlemleri neticesinde, adliye binası (Ankara Adalet Sarayı-Sıhhiye) içerisinde aile mahkemeleri koridorlarında vatandaşların bilgi edinebilecekleri bilgi bankolarının yer almadığı sonucuna ulaşılmıştır. Ayrıca duruşma gözlemlerinde, tarafların dava süreci ve hukukun uygulanması usulü ile ilgili bilgi boşlukları olduğu gözlemlenmiştir. Boşanmanın yasal boyutuna ilişkin bilgi eksikliğinin ise taraflar açısından bu süreçteki çatışmaları artırıcı bir etkiye sahip olabileceği düşünülmektedir.

Tablo 4: Aile Yaşam Döngüsünde Ailenin Konumu

\begin{tabular}{lll}
\hline Aile Yaşam Döngüsü & $\mathbf{N}$ & $\mathbf{\%}$ \\
\hline Yeni Evli Aile & 57 & 32,8 \\
\hline Çocuğu Olan Aile & 96 & 55,2 \\
\hline Ergen Çocuğu Olan Aile & 9 & 5,2 \\
\hline Çocukların Evden Ayrilı̧̧ı & 8 & 4,6 \\
\hline Yaşlı Aile & 4 & 2,3 \\
\hline Toplam & 174 & 100,0 \\
\hline
\end{tabular}

Boşanma davalarında dikkat çeken bir diğer önemli veri de çiftlerin boşanma sürecine kadar geçen zaman diliminde aile sistemine ne kadar süre dâhil oldukları ile ilgilidir. Tablo 4'e göre, davaları devam eden tarafların $\% 55,2$ 'si çocuğu olan aile gurubuna aitken, bunu \%32,8 ile yeni evli aileler, $\% 5,2$ ile ergen çocuğu olan aileler ve \%4,6 ile çocukların evden ayrıldığı dönemdeki aileler takip etmektedir. Yaşlı aileler ise diğer gruplardan çok daha az bir yüzdeye sahiptir. Tablo 4'e göre, evliliğin ilerleyen yıllarında boşanma oranlarında düşüş yaşandığı sonucu ortaya çımaktadır.

Pek çok çalışma, çiftlerin evliliklerinin hangi yıllarında boşanmaya karar verdiklerini ortaya koymaktadır. Türkiye İstatistik Kurumu 2018 verilerine göre, 2017 yılında gerçekleşen boşanmaların \%38,7'si evliliğin ilk 5 yılı, \%20,7'si ise evliliğin 6-10 yılı içinde gerçekleşmiştir (TÜİK, 2018). Dolayısıyla bu veriler araştırma verileri ile uyumludur.

Tablo 5. Müş̧terek Çocuk Sayısı

\begin{tabular}{lllll}
\hline \multirow{2}{*}{ Sayı } & \multicolumn{2}{l}{ Müşterek Çocuk Sayısı } & \multicolumn{2}{l}{$\mathbf{1 8}$ Yaş Altı Müşterek Çocuk Sayısı } \\
\cline { 2 - 5 } & $\mathrm{N}$ & $\%$ & $\mathrm{~N}$ & $\%$ \\
\hline 1 & 69 & 59,5 & 74 & 69,2 \\
\hline 2 & 39 & 33,6 & 28 & 26,2 \\
\hline 3 & 6 & 5,2 & 5 & 4,7 \\
\hline 4 & 2 & 1,7 & 0 & 0,0 \\
\hline Toplam & 116 & 100,0 & 107 & 100,0 \\
\hline
\end{tabular}


Buna ek olarak tablo 5'e göre, tarafların \%58'i müşterek çocuğa sahiptir. Tarafların \%59,5'i bir tane çocuğa sahipken, \%33,6'sı iki tane, \%6,9'u ise üçten fazla çocuğa sahiptir. Bu durum boşanma davalarının yarıya yakınının diğer yandan velayet, kişisel ilişki tesisi konularını da kapsadığını ortaya koymaktadir.

Tablo 6. Tarafların Boşanma Sürecinde İkamet Ettikleri Yer

\begin{tabular}{lllll}
\hline \multirow{2}{*}{ İkamet } & Kadın & \multicolumn{3}{l}{ Erkek } \\
\cline { 2 - 5 } & $\mathrm{N}$ & $\%$ & $\mathrm{~N}$ & $\%$ \\
\hline Aile Konutu & 21 & 33,9 & 33 & 57,9 \\
\hline Kök Aile Yanı & 30 & 48,4 & 9 & 15,8 \\
\hline Kardeş Yanı & 1 & 1,6 & 2 & 3,5 \\
\hline Çocuklarının Yanı & 2 & 3,2 & 1 & 1,8 \\
\hline Yeni Bir Ev Kira & 6 & 9,7 & 12 & 21,1 \\
\hline Sı̆̆ınma evi & 1 & 1,6 & 0 & 0,0 \\
\hline Başka Birinin Yanı & 1 & 1,6 & 0 & 0,0 \\
\hline Toplam & 62 & 100,0 & 57 & 100,0 \\
\hline
\end{tabular}

Yukarıda yer alan tablo 6, boşanma sürecinde çiftlerin ikamet ettikleri yer ile ilgilidir. Ancak duruşma esnasında mahkemeye sözlü olarak sunulan bilgilerden elde edilen verilere bağlı kalındığından 200 dosyanın 62 tanesinde tarafların şu anda ikamet ettikleri yere ilişkin bilgilere ulaşılmıştır. Buna göre, kadınların \%48,4'ü bu süreci kök ailelerin yanında atlatırken, \%33,9'u aile konutunda kalmaya devam etmektedir. Erkeklerde ise bu durum biraz daha farklıdır. Erkeklerin \%57,9'u aile konutunda kalmaya devam ederken \%21,1'i yeni bir evde (kirada) yaşamayı tercih etmektedir. Yalnızca \%15,8'i kök aile yanında yaşamaktadır.

Yapılan başka bir araştırmada kadınların, boşandıktan sonraki yaşam alanları belirlenmeye çalışılmıştır. Katılımcıların \%45,7'si “Babamın, annemin evine giderim", \%22,0'si "Evimde otururum, hiçbir yere gitmem", \%14,2'si "Ev tutar, yalnız yaşarım", \%8,3'u' “Çocuklarımın yanına giderim”, \%3,3'ü "Çalışır, ayaklarımın üstünde dururum" demişlerdir. Boşanmaları durumunda evli kadınların yaşamlarını sürdürmek istedikleri mekânlar konusundaki eğilimleri bize, Türk toplumunda en dayanılacak/güvenilecek kurumun aile ve akrabalık sitemi olduğunu ortaya koymaktadır. "Arkamda kapı gibi ailem var," deyişi de bu yargımızı desteklemektedir (Çakır, 2012). 
Boşanmaya giden yolda kadınların en büyük destekçilerinin kök aileleri olduğu görülmektedir. Baba evine dönmek kadınlara, aile konutunda kalmak erkeklere özgü bir davranış olarak ortaya çıkmıştır. Toplumsal cinsiyet paradigması içinde erkeğe atfedilen "Ceketimi alır evi terk ederim" deyişinin gündelik hayatta karşılıksız kalması, kadına "Baba evine dönme" nin kapılarını açıyor gibi görünmektedir.

Tablo 7. Tarafların Ayrılma Biçimi

\begin{tabular}{lll}
\hline Tarafların Ayrılma Biçimi & $\mathbf{N}$ & $\mathbf{\%}$ \\
\hline Kök Aileden Birini Çağırma & 12 & 22,6 \\
\hline Evden Ayrılma & 31 & 58,5 \\
\hline $\begin{array}{l}\text { Erkeğin Ailesinin Kadının Eşyalarını Kapının Önüne Ko- } \\
\text { yması }\end{array}$ & 1 & 1,9 \\
\hline Erkeğin Babasının Kadının Ailesini Arayıp Haber Vermesi & 2 & 3,8 \\
\hline Karakola Başvuru ve Uzaklaştırma Kararı & 7 & 13,2 \\
\hline Toplam & 53 & 100,0 \\
\hline
\end{tabular}

Duruşmada dinlenen tanıkların beyanlarından elde edilen bilgiler 1şığında 53 duruşmada tanıklar, duruşmanın içeriği gereği, tarafların en son nasıl ayrıldıklarına ilişkin beyanda bulunmuşlardır. Tanıkların bazıları bizzat son ayrılığa şahit olduklarını belirtirken bazıları taraflardan duyduklarını beyan etmişlerdir.

Tablo 7'ye göre tarafların yarısından fazlası, $\% 58,5^{\prime}$ lik kısmı, taraflardan birinin evden ayrılması ile fiziksel ayrılığı deneyimlerken bunu \%22,6'lık bir oranla taraflardan birinin kök ailesini çağırması izlemektedir. \%13,2'lik k1sımda ise tarafların fiziksel ayrılıkları devlet kontrolünde gerçekleşmiş ve erkeğe yönelik uzaklaştırma kararı çıkarılmıştır.

Boşanma çalışmalarına ilişkin literatür incelendiğinde, ilişkinin dağılma evrelerine ilişkin sınıflandırmalarla karşılaşılır. Araştırmacılar bu evreleri farklı şekillerde sınıflandırmışlardır. Örneğin, Duck (1984; Weber ve Harvey, 1994; akt: Dönmez ve diğerleri, 2009) çözülme evresi, iç ruhsal evre, ikili evre, toplumsal eure ve son olarak da kefenleme evrelerinden söz eder. Çiftlerden birisinin ilişkide doyumsuzluk yaşamasıyla başlayan dağılma süreci nihayetinde kefenleme evresi ile sona erer. Kuşkusuz kefenleme evresi ayrıllğın fiziksel olarak da görünür hale geldiği ve çiftlerin yollarını ayırdığı evredir. Tüm diğer evrelerde olduğu gibi fiziksel ayrılık evresi de çiftlerin yaşam stillerine, 
aile yapılarına, kök ailelerle olan sınırlara, menfaat çatışmalarına, yaş ve cinsiyetlerine, çocuk sahibi olma durumlarına, çocuklarının yaşlarına, aile yaşam döngüsündeki konumlarına, evlilik sürecinde içinde bulundukları çatışma konularına ve bu yaşanan çatışmaların sıklık, yoğunluk ve düzeyine göre farklılık göstermektedir.

Bu bilgiler ışı̆̆ında, boşanma sürecinde tarafların yaşadıkları çatışma deneyimlerinin somut olarak resmedilmesi amacıyla aşağıda mahkeme huzurunda dinlenen tanıkların, tarafların nasıl ayrıldıklarına ilişkin beyanları aktarılmıştır. Birinci ve ikinci vaka (dosya no 101 ve dosya no 98), kadının, kök ailesinden birini çağırması ile ilgili örneklerdir.

[101] "...Babası kızımı aradı, o evden çıksın [damadından bahsediyor] benim elimi kana bulamayın dedi. Biz gittiğimizde damadım evde yoktu. Karakola gittik gerekli işlemleri yaptırdık, Ankara'ya döndük..." (Dosya no 101, çekişmeli boşanma, davacı kadının annesinin tanık olarak beyanı)

[98] "Babası (adamın) bir suçtan dolayı tutuklanmıştı, bu yüzden kızım da tehdit ediliyordu. Bunun üzerine kızımı eve getirdim. Kızım eve geldikten sonra aynı gün dayısı ve kız kardeşi (adamın) geldiler, evin anahtarını istediler. Kızım da hiç tepki göstermeden evin anahtarın verdi. Daha sonra hiçbir şekilde iletişim kurulmadı (Dosya no 98, çekişmeli boşanma, davacı kadının annesinin tanı olarak beyanı)

Yukarıdaki vakalarda olduğu gibi kadınlar bazı durumlarda tek başlarına evden kaçmak konusunda yeterli güce sahip olamamakta ve aile yakınlarından destek istemektedirler. Ancak bu vakalardan bazılarında ise kadını "kurtarmak" adına tarafların evlerine giden aile yakınlarının da ev içi erkek şiddetine maruz kaldıkları ya da diğer aile üyelerinin bizzat çatışmanın aktörü haline geldiği durumlar beyan edilmiştir.

[89] "... En son ablamla tartıştılar, bana bıçak ve silah çekti. Kim önüme gelirse öldürürüm dedi. En son polisi aradık. Uzaklaştırma kararı aldı." (Dosya no 89, çekişmeli boşanma, davacı kadının erkek kardeşinin tanık olarak beyanı)

[136] "... En son, kızım ağlayarak telefon etti. Evlerine gittim, kızım yatak odasında ă̆lıyordu. Sonra kaynı sinirle geldi. Normalde kızımı severdi. O, evde yoktu (damadın kastediyor) Kayınpeder ve kayınvalidesi vardı. Kaynı karşı apartmanda oturuyordu. Kaynı, küfürler ederek al kızın git dedi...Kayınvalidesi naylon poşet verdi. Çıkmamız için acele ediyorlardı. Eve polis çă̆ırdım, polis gelmeden evden çıktık. Damat ortada yoktu. Kayınvalide, kayınpeder torunu da ite ite haydi kızım gidin diyordu. Kızımın evden son ayrılışı bu" (Dosya no 136, çekişmeli boşanma, tahkikat aşması, davacı kadının annesinin tanık olarak beyanı) 
Tarafların en son ayrılma biçimleri incelendiğinde özellikle kadınların bu süreçte kök aile desteğine daha ihtiyaç duydukları gözlemlenmiştir. Ev içi erkek şiddetin olduğu evliliklerde ayrılık daha şiddetli bir hal alarak diğer aile üyelerini de etkisi altına alabilmektedir. Bu nedenle özellikle ev içi şiddet konusunda çalışmalar yürütülürken tüm aile üyelerini kapsayıı olmasına özen gösterilmelidir.

\section{Davaya İlişkin Bulgular}

Yargının işlevi, kural olarak, çekişmeli olayları bir dava biçiminde incelemek ve bir yargı kararı ile sonuçlandırmaktır. Çekişmenin taraflarından biri mahkemeye başvurup, haklarının korunması istemini usulüne uygun biçimde bildirdiğinde, dava açılmış; yani taraflar arasındaki çekişme davaya dönüşmüş olur. Davanın açılmasından sonra, davanın tarafları arasındaki ilişki "dava ilişkisi" dir (Aybay ve diğerleri, 2018). Bu bölümde, dava ilişkisi içinde davaya ve davanın hükme bağlanmasına ilişkin veriler aktarılmıştır.

Tablo 8. Davanin Nev'i

\begin{tabular}{lll}
\hline Davanın Nev'i & N & \% \\
\hline Çekişmeli & 137 & 68,5 \\
\hline Anlaşmalı & 51 & 25,5 \\
\hline Velayetin Yeniden Düzenlenmesi & 7 & 3,5 \\
\hline Nafakanın Yeniden Düzenlenmesi & 4 & 2,0 \\
\hline Mal Paylaşımı & 1 &, 5 \\
\hline Toplam & 200 & 100,0 \\
\hline
\end{tabular}

Tablo 8'e göre, duruşmaların \%68,5'i çekişmeli boşanma davalarından, $\% 25,5^{\prime}$ i anlaşmalı boşanma davalarından oluşmaktadır.

Boşanma davalarında davanın çekişmeli ya da anlaşmalı olarak açılması oldukça önemlidir. Çünkü bu durum dosyanın seyrini ve boşanma usulünü belirler. Çekişmeli boşanmalarda ön inceleme, tahkikat, sözlü yargılama aşamaları söz konusu iken anlaşmalı boşanmalarda tarafların mahkemeye bir sözleşme (protokol) sunmaları ve bu sözleşmeyi hâkimin onaylaması yeterli$\operatorname{dir}(\mathrm{TMK}, \mathrm{m} .184 / 5)$.

Boşanma çalışmalarında özellikle üzerinde durulması gereken konulardan birisi de anlaşmalı boşanmalarla çekişmeli boşanmalar arasındaki ayrı- 
mın doğru bir şekilde yapılmasıdır. Anlaşmalı boşanma davalarında tam anlamıyla barışçıl bir boşanma sürecinden bahsetmek mümkün değildir. Bu tür davalarda çiftler, sadece boşanmanın yasal boyutunda aralarındaki çatışmaları asgari düzeye indirerek bir anlaşmaya varmış olabilir. Bunun yanı sıra çiftler arasındaki bu yasal anlaşma da her zaman iki tarafın da üzerinde anlaştığı, kabul ettiği, adil ve herkesin memnun kaldığı bir sözleşmeyi içermeyebilir.

Aslında, tarafsız ve adil olduğu düşünülen süreçler çoğu zaman nitelikli anlaşmalar doğursa da çalışmalar arabuluculukların hala çkmazlarla sonuçlanabileceğini göstermiştir (Pearson and Thoennes 1989; Kressel 1997; akt: Baitar ve diğerleri, 2012). Ek olarak, birisinin bir anlaşmayı imzalamayı kabul etmesi, onun öznel olarak bunu nitelikli bir anlaşma olarak tecrübe ettiği anlamına gelmemektedir (Poitras and Le Tareau 2009; akt: Baitar ve diğerleri, 2012).

Tablo 9. Davanın Hükme Bağlanmasına İlişkin Veriler

\begin{tabular}{lll}
\hline Dosyanın Hangi Aşamada Olduğu & $\mathbf{N}$ & $\mathbf{\%}$ \\
\hline Ön İnceleme & 42 & 21,0 \\
\hline Tahkikat & 86 & 43,0 \\
\hline Sözlü Yargılama & 72 & 36,0 \\
\hline Toplam & 200 & 100,0 \\
\hline Dosyanın Karara Bağlanması & & \\
\hline Tarafların Boşanmalarına & 65 & 91,5 \\
\hline Davanın Reddine & 4 & 5,6 \\
\hline Feragat & 2 & 2,8 \\
\hline Toplam & 71 & 100,0 \\
\hline Velayet Kararı & & \\
\hline Anne & 33 & 84,6 \\
\hline Baba & 6 & 15,4 \\
\hline Toplam & 39 & 100,0 \\
\hline
\end{tabular}

Tablo 9'a göre, takip edilen 200 dosyadan $\% 21,0$ 'i tanesi ön inceleme, $\% 43,0^{\prime} \ddot{u}$ tahkikat ve $\% 36,0^{\prime}$ sı sözlü yargılama aşamasındadır.

Özel hukuk davalarına, uygulamada, kısaca "hukuk davaları" denir. Bu davalar tarafların karşılıklı olarak ileri sürdükleri olgulardan ve savlardan oluşan bir çerçeve içinde görülüp hükme bağlanır (Aybay ve diğerleri, 2018). Tablo 9'a göre, 200 duruşmadan \%35,5 dava karara bağlanmış ve hüküm verilmiştir. Boşanma davalarmda mahkeme, usule veya esasa ilişkin bir nihai kararla 
davayı sona erdirir. Yargılama sonunda uyuşmazlı̆̆ın esası hakkında verilen nihai karar, hükümdür (HMK, m. 294/1).

Bu kararlardan \%91,5'inde tarafların boşanmalarına karar verilirken davaların \%5,6'sı usulen reddedilmiştir. Yasaya göre, mahkeme, dava şartlarının mevcut olmadığını, davanın her aşamasında kendiliğinden araştırı. Taraflar da dava şartı noksanlığın her zaman ileri sürebilirler. Mahkeme, dava şartı noksanlığını tespit ederse davanin usulden reddine karar verir (HMK m.115 f.1-2). Çünkü yasaya göre, Kanunda aksine bir hüküm bulunmadıkça, taraflardan her biri, hakkını dayandırdığı olguların varlı̆̆ın ispatlamakla yükümlüdür (TMK, m.6).

Usulen reddedilen davalarda, reddedilme nedenleri belirgin şekilde tarafların ve özellikle davayı açan kadınların boşanma ile ilgili yasal adımları takip etme konusunda yeterli bilgiye sahip olmayışları şeklinde gözlemlenmiştir.

Halen devam eden kadın erkek eşitsizliği, toplumsal cinsiyete dayalı ön yargılar ve cinsiyet kalıp yargıları kadın ve erkeklerin adalete eşit olmayan bir şekilde erişmeleri ile sonuçlanmaktadır. Kadınların önünde bulunan engeller arasında yeterli farkındalığın bulunmaması, özgüven ve kaynak eksikliği, toplumsal cinsiyet ön yargıları, sosyal ve ekonomik engeller yer almaktadır. Bu engeller özellikle çeşitli ayrımcılığa maruz kalmış şiddet mağduru kadınlar ve savunmasız durumda olan kadınlar açısından büyük önem arz etmektedir (Avrupa Konseyi, 2014-2017). Oysa adalete erişim, kişilerin hakların bilmeleri ve bu haklarına etkili biçimde erişebilmeleri için devletin desteğiyle her türlü önlemin hukuk sistemi tarafından alınmasıdır (Adalet bakanlığı stratejik planı, 2015-2019).

Tablo 9'a göre, boşanmaya karar verilen davalardan \%19,5'inde velayet konusunda da karar verilmiştir. Buna göre, \%84,6 dosyada velayet anneye verilirken $\% 15,4$ 'ünde velayet babaya verilmiştir. Velayetin kadınlara verilmesi içselleştirilmiş bir uygulamadır. Toplumsal kabuller çocuğun yerinin annenin yanı olduğunu ifade etme eğilimindedir.

Çünkü kadın, piyasanın temsil ettiği iş alanından dışlanmakta, ev kadının alanı haline gelmektedir. Kadın, ev içi emeğinin sahibi olarak, ailenin yeniden üretiminden sorumlu olan bireydir (Ecevit ve Karkıner, 2011). Bu sebeple ev işleri ve çocuk bakımı kadının sorumluluk alanına dahil edilmekte ve velayet kararlarında da bu durumun yeniden üretimi söz konusu olmaktadır. 


\section{Anlatılmayan Öykü: Duruşmalara İlişkin Bulgular}

Bu bölüm, daha önce anlatılmayan, duruşma salonlarının ardında kalan boşanma hikâyelerini gün yüzüne çıkarmak üzere hazırlanmıştır. Aşağıda duruşma salonlarında yaşanan olaylara ilişkin bulgulara yer verilmiştir.

Tarafların mahkeme huzurunda hazır bulunmaları önemlidir. Tablo 10'a göre, kadınların \%73,0'ü duruşmalara katılırken, erkeklerin \%65,5'i duruşmalara katılmıştır. Duruşmalara katılım konusunda kadınlar ve erkekler arasinda eşit bir dağılım görülmemektedir.

Tablo 10. Tarafların Duruşmaya Katılma Durumu ile Dosyanın Aşaması

\begin{tabular}{|c|c|c|c|c|c|c|c|c|}
\hline \multirow{3}{*}{ Erkek } & \multicolumn{8}{|c|}{ Dosyanın Hangi Aşamada Olduğu } \\
\hline & \multicolumn{2}{|c|}{ Ön inceleme } & \multicolumn{2}{|c|}{ Tahkikat } & \multicolumn{2}{|c|}{ Sözlü Yargılama } & \multicolumn{2}{|c|}{ Toplam } \\
\hline & $\mathrm{N}$ & $\%$ & $\mathrm{~N}$ & $\%$ & $\mathrm{~N}$ & $\%$ & $\mathrm{~N}$ & $\%$ \\
\hline Evet & 25 & 59,5 & 44 & 51,2 & 62 & 86,0 & 131 & 65,5 \\
\hline Hayır & 17 & 40,5 & 42 & 48,8 & 10 & 14,0 & 69 & 34,5 \\
\hline Toplam & 42 & 100,0 & 86 & 100,0 & 72 & 100,0 & 200 & 100,0 \\
\hline \multicolumn{9}{|l|}{ Kadın } \\
\hline Evet & 23 & 54,8 & 58 & 67,4 & 65 & 90,3 & 146 & 73,0 \\
\hline Hayır & 19 & 45,2 & 28 & 32,6 & 7 & 9,7 & 54 & 27,0 \\
\hline Toplam & 42 & 100,0 & 86 & 100,0 & 72 & 100,0 & 200 & 100,0 \\
\hline
\end{tabular}

Kadınların duruşmalarda daha fazla yer edinmesi, pek çok farklı sebeplerden kaynaklanıyor olabilir. Beauvoir (2010)'e göre, kadının herhangi bir şey yapmasına, dolayısıyla kendini yetkin bir kişi olarak kabul ettirmesine izin verilmez. Kadın, ne denli sayılırsa sayılsın, erkeğe bağll, ikinci planda kalan bir varlıktır. Bu yüzden de aile içi yaşamdaki başarı ya da başarısızlık onun için erkekten çok daha önemlidir. Erkeğin yurttaşlı̆̆ı üreticiliği kocallğından önce gelir; kadınsa her şeyden önce, çoğu kez yalnızca eştir. Bu sebepledir ki, belki de hayatlarının tek ve yegâne amacı ile ilgili karar alınırken orada olmak, onların kimliklerini yeniden inşa etme sürecine katılımı açısından önemlidir.

Kadınların duruşma salonunda yer almalarına ilişkin analizin yanı sıra erkeklerin neden kendi davaları ile ilgili daha az katılım gösterdikleri de yorum gerektiren bir başka boyuttur. Duruşmalara katılım, ev içi sorumlulukların devamında yer alan bir durum olarak ele alınabilir. Böyle bir yorumda, erkeklerin duruşma salonundaki yokluğu, kadınların beyan ettikleri evlilik 
içinde yaşanan çatışma konularının kayda değer bir yüzdesini oluşturan "erkeğin sorumsuz ve ilgisiz olması" ile ilişkilendirilebilir. Evlilik içinde sorumsuz ve ilgisiz olan erkek, boşanma sürecinde de ilgisiz tavrını koruyor olabilir.

Bir diğer önemli nokta ise, davanın daha çok hangi aşamasında duruşmaya katılım gösterme eğiliminde olduklarıdır. Tablo 10'a göre hem erkekler hem de kadınlar davanın ilk aşaması olan ön inceleme aşamasına katılım noktasında çekingen davranırken ikinci aşama tahkikat aşamasına daha fazla katılım göstermektedir; ancak katılımın yoğun olduğu aşama, davanın hükme bağlandığı sözlü yargılama aşamasıdır.

Tarafların ön inceleme duruşmasına katılımlarının diğer duruşmalara oranla daha az olması çatışma yönetimi açısından olumsuzdur. Çünkü mahkeme ön incelemede; dava şartlarını ve ilk itirazları inceler, uyuşmazlık konularını tam olarak belirler, hazırlık işlemleri ile tarafların delillerini sunmaları ve delillerin toplanması için gereken işlemleri yapar, tarafların üzerinde serbestçe tasarruf edebileceği davalarda onları sulha veya arabuluculuğa teşvik eder ve bu hususları tutanağa geçirir (HMK m.137/1).

Ancak matbu şeklinde gerçekleştirilen ön inceleme, şekli bir inceleme olarak kalacak ve tarafların hayatlarına dokunamayacaktır. Taraflar arasında yasal boşanmanın daha ilk aşamasında doğru müdahaleyi geliştirebilmek (örneğin dosyanın uzmana ya da aile terapisine yönlendirilmesi, sulha teşvik, tedbir kararlarının belirlenmesi, vb.) ve ilerleyen bölümlerde oluşacak olan kötü senaryoların önüne geçilmesine firsat vermek adına ön inceleme duruşması, üzerinde durulması gereken önceliğe sahiptir.

Tablo 11. Duruşma Salonunda Bulunan Yakınlar

\begin{tabular}{lllll}
\hline Salonda Bulunma Durumu & \multicolumn{2}{l}{ Kadının Yakını } & \multicolumn{2}{l}{ Erkeğin Yakını } \\
\cline { 2 - 5 } & $\mathrm{N}$ & $\%$ & $\mathrm{~N}$ & $\%$ \\
\hline Evet & 51 & 66,0 & 28 & 43,0 \\
\hline Hayır & 26 & 34,0 & 37 & 57,0 \\
\hline Toplam & 77 & 100,0 & 65 & 100,0 \\
\hline
\end{tabular}

Tablo 11'e göre, duruşmaya katılan bir diğer grup ise ailenin daha geniş üyelerinden oluşmaktadır. Kök aile üyeleri özellikle bu grup içerisinde daha fazla duruşmalara katılan gruptur. Kuzen, arkadaş ve diğer aile yakınları duruşmayı takip eden diğer izleyicilerdir. Tarafların yakınlarının duruşmaya katılımı, kadınlarda ve erkeklerde değişiklik göstermektedir. Kadınların 
\%66,0'sının erkeklerin ise \%43,0'nün yakınlarının duruşma salonunda olduğu gözlemlenmiştir.

Kadınların erkeklere oranla duruşmalara sıklıkla yakınları ile gelmesi bir tartışmayı gündeme getirmektedir. Acaba, kadınlar mı duruşmalara yakınları ile gelmeyi tercih etmektedir yoksa tıpkı evliliklerinde ve kadının hayatının diğer tüm aşamalarda olduğu gibi, aile yakınları mı kadını duruşma salonunda yalnız bırakmak istememektedir. Bir diğer açıdan aile yakınlarının duruşma salonunda olmalarının anlamı belki de onların kadın için duruşma salonunda güvenlik duvarı olmalarıdır. Özellikle; tehditlerin, şiddetin bir tür çatışma ve kendini ifade etme aracı olarak kullanıldı ̆̆ı evliliklerde, aile yakınları mahkeme sürecinde devlet eliyle sağlanamayan korumanın aracı haline gelebilirler.

Tablo 12. Duruşma Salonunda Çatışma Yaşanma Durumu

\begin{tabular}{lllllll}
\hline Duruşma Salonunda & \multicolumn{2}{l}{ Taraflar arası } & \multicolumn{2}{l}{ Avukatlar arası } & \multicolumn{2}{l}{ Yakınlar arası } \\
\cline { 2 - 8 } ÇatışmaYaşanma Durumu & $\mathrm{N}$ & $\%$ & $\mathrm{~N}$ & $\%$ & $\mathrm{~N}$ & $\%$ \\
\hline Evet & 19 & 17,3 & 8 & 8,2 & 8 & 16,0 \\
\hline Hayır & 91 & 82,7 & 90 & 91,8 & 42 & 84,0 \\
\hline Toplam & 110 & 100,0 & 98 & 100,0 & 50 & 100,0 \\
\hline
\end{tabular}

Tablo 12'ye göre, taraflardan her ikisinin de duruşma salonunda olduğu durumda taraflar arasında çatışma yaşanma durumu \%17,3, avukatlardan her ikisinin de duruşma salonunda olduğu durumda avukatlar arasında çatışma yaşanma durumu \%8,2, her iki tarafın da yakınlarının duruşma salonunda olduğu durumda yakınlar arasında çatışma yaşanma durumu ise $\% 16,0$ 'dir.

Duruşma salonları, çatışma ritminin yüksek olduğu mekânlardır. Her an çatışma yaşanması muhtemel olduğu için duruşma salonlarında nefes alıp verirken havaya sadece karbondioksit değil biraz da "dracarys" (ejderha ateşi) yayılır. Çünkü yargılamada "eşitlik" denildiği zaman, ilk anımsanan çekişmeli yargılama olmaktadır.

Çekişmeli yargılama ancak, karşıtların birlikteliği ile gerçekleşebilir. Sözleşme (Avrupa İnsan Hakları)'nin 6. maddesinin 1. bendine göre karşıtlar, ceza yargılamasında kendisine bir suç yüklenilen kişi ile onu suçlayan kamu görevlisi ya da suçtan etkilenen bir başka kişi olurken "Medeni ve hukuki uyuşmazlıkların" karşıtları ise davacılar ve davalılardır (Dinç, 2005). 
Duruşma salonunda yaşanan çatışmalar, yukarıda bahsedildiği gibi farklı gruplar arasında gözlemlenmiştir. Ancak çatışmanın kaynağı her zaman, aralarında çatışma yaşanan gruplar olmamıştır. Bazı dosyalarda, hâkim yaşanan gerilimi azaltma yolunu seçerken bazı hâkimler gruplar arasındaki çatışmaların bizzat kaynağı olmuştur. Aşağıda bu duruma özgü bir gözleme yer verilmiştir:

[146] (Tanıklar dinlenirken taraflar arasında karşılıklı sözlü atısmalar oldu) Hâkim: "İki taraftan biri yalan söylüyor. Yalan söyleyen taraf cehenneme gitsin." dedi. Dinleyici bölümünde her iki tarafin da yakmları vardı. Hâkimin bu ifadesinden sonra sesler yükseldi. Bir süre tartışma oldu. Sonra mübaşir iki tarafı da dışarn çıkardı. Duruşma salonunun kapısı kapandıktan sonra büyük bir gürültü geldi. Hâkim bir sonraki duruşmaya devam etti (Dosya no 146, çekişmeli boşanma, tahkikat aşaması)

[21] Duruşmada, müşterek çocuklarm tanık olarak dinlenmesi esnasında çocuklar ve anne arasında tartışma yaşandl. Çocuklarm beyanları dinlenirken, özellikle küçük çocuğun anne ve babasının kendisine şiddet uyguladı̆̆ın ve onlar bunu yaptı̆̆ında çok sinirlendiğini ifade ettiğinde önce anne ve babanın gözleri dolmuş, büyük çocu$\breve{g}$ un da annelerinin kendilerine şiddet uyguladı̆̆ına yönelik beyanı sonrasinda anne ve çocuk arasında karşıllklı tartışma yaşanmıştır. Bunun üzerine hâkim hem çocuklarm beyanlarna dayanarak hem de duruşma salonunda yaşananlarn göz önünde bulundurarak her iki tarafı da öfke kontrolü eğitimine yönlendirmiştir (Dosya no 21, çekişmeli boşanma, tahkikat aşaması).

Tablo 13. Duruşma Salonunda Çatışma Yaşanma Durumu ile Dosyanın Aşaması

\begin{tabular}{lllllllll}
\hline \multirow{2}{*}{$\begin{array}{l}\text { Salonda Taraflar } \\
\text { Arasında Çatışma } \\
\text { Yaşanma Durumu }\end{array}$} & \multicolumn{6}{l}{ Dosyanın Hangi Aşamada Olduğu } \\
\cline { 2 - 11 } & \multicolumn{2}{l}{ Ön inceleme } & \multicolumn{2}{l}{ Tahkikat } & \multicolumn{2}{l}{ Sözlü Yargılama } & \multicolumn{2}{l}{ Toplam } \\
\cline { 2 - 11 } & $\mathrm{N}$ & $\%$ & $\mathrm{~N}$ & $\%$ & $\mathrm{~N}$ & $\%$ & $\mathrm{~N}$ & $\%$ \\
\hline Evet & 2 & 10,5 & 14 & 73,7 & 3 & 15,8 & 19 & 100,0 \\
\hline Hayır & 11 & 12,1 & 22 & 24,2 & 58 & 63,7 & 91 & 100,0 \\
\hline Kadın yok & 12 & 48,0 & 10 & 40,0 & 3 & 12,0 & 25 & 100,0 \\
\hline Erkek yok & 10 & 26,3 & 23 & 60,5 & 5 & 13,2 & 38 & 100,0 \\
\hline Her iki taraf da yok & 7 & 25,9 & 17 & 63,0 & 3 & 11,1 & 27 & 100,0 \\
\hline Toplam & 42 & & 86 & & 72 & & 200 & \\
\hline
\end{tabular}

Tablo 13'e göre, duruşma salonunda taraflar arasında yaşanan çatışmaların \%10,5'i ön inceleme aşamasında, \%73,7'si tahkikat aşamasında, \%15,8'i ise sözlü yargılama aşamasında gerçekleşmiştir. Taraflar arasındaki çatışmanın tahkikat aşamasında diğer aşamalara oranla daha yüksek olmasının bir se- 
bebi, tanıkların tahkikat aşamasında dinlenmesi ve delillerin bu aşamada sunulmasıdır. Yasaya göre; tahkikat aşamasında tarafların davada ileri sürdükleri bütün iddia ve savunmalar birlikte incelenir (HMK m.143/1). Hâkim taraflarm iddia ve savunmalarıla toplanan delilleri inceledikten sonra duruşmada hazır bulunan taraflara tahkikatın tümü hakkında açıklama yapabilmeleri için söz verir (HMK m. 184/1).

Sunulan deliller ve tanıkların beyanı tarafların kendi haklılıklarını ortaya koyma çabasını taşır. Taraflar bu aşamada davalarında haklı olduklarını ve karşı tarafın haksız olduğunu ispat etmekle yükümlüdürler. Karşı tarafın haksızlığını ortaya koymak en masum düşünce de bile "suçluyu bulmayı" gerekli kılar. Kuşkusuz bu aşama çiftlerin tam anlamıyla belirgin bir şekilde birbirlerine karşı taraf oldukları aşamadır. Bu sebeple menfaat çatışmalarına zemin hazırlaması kaçınılmazdır.

\section{Çatışma Konularına İlişkin Bulgular}

Çalışmanın bu bölümünde, ilk olarak evlilik içinde yaşanan çatışma konuları ve sonrasında, bu çatışmaların neticesinde boşanma sürecine gelen tarafların boşanma sürecinde yaşadıkları çatışma konuları ele alınmıştır. Dolayısıyla bu çalışmada, evlilik içerisinde yaşanan çatışmalar "boşanma nedenlerinin öncüleri" olarak ele alınmıştır.

Tablo 14. Evlilik Sürecinde Çatışma Konuları

\begin{tabular}{lll}
\hline Evlilik Sürecinde Çatışma Konuları & $\mathbf{N}$ & $\mathbf{\%}$ \\
\hline Aldatma & 31 & 7,9 \\
\hline Şiddet & 45 & 11,5 \\
\hline Sorumsuz Davranma & 53 & 13,5 \\
\hline Özel Günleri Birlikte Kutlamama & 10 & 2,5 \\
\hline Kök Aile Sorunları & 64 & 16,3 \\
\hline Kötü Söz- Hakaret- Tehdit & 56 & 14,3 \\
\hline Başkalarının Yanında Aşağılama & 17 & 4,3 \\
\hline Misafir İstememe & 5 & 1,3 \\
\hline Ekonomik Meseleler & 55 & 14,0 \\
\hline Cinsel Sorunlar & 12 & 3,1 \\
\hline Ruhsal Sorunlar & 12 & 3,1 \\
\hline Sağlık Sorunları & 8 & 2.0 \\
\hline Alkol-Uyuşturucu Kullanımı & 14 & 3,6 \\
\hline Erkeğin Başka Birinden Çocuğunun Olması & 5 & 1,3 \\
\hline Üvey Çocuklar & 5 & 1,3 \\
\hline Toplam & 392 & 100,0 \\
\hline
\end{tabular}


Geniş boyutta anlaşmazlıklar, uzlaşmazlıklar, düşmanlıklar ve çatışmalar olmaksızın bir ailede büyümek, bir komşuluk yaşamak, okula gitmek, işte çalışmak, yakın bir ilişki kurmak, çocuk yetiştirmek ya da bir vatandaş olarak aktif bir şekilde yaşamak neredeyse imkânsızdır (Cloke ve Goldsmith, 2018). Çatışmalar doğal hayatın bir parçasıdır. Evlilik ilişkisi de bu doğal çatışma alanlarından birisidir. Tablo 14'te evlilik sürecinde yaşanan çatışma konuları ele alınmıştır.

Tablo 14'te bahsedilen evlilik sürecinde çatışma konuları tarafların beyanları, tanıkların ifadeleri ile sınırlıdır. Ayrıca her bir dosyada birden fazla çatışma konusu gündeme geldiği için çatışma konularının toplamı 200'den fazla çikmıştır. Buna ek olarak anlaşmalı boşanmalarda, tarafların hazırlamış olduğu protokol metni (sözleşme) üzerinden işlem yapıldığı için bu davalarda çatışma konularına ilişkin veri elde edilememiştir.

Tablo 14'e göre, evlilik sürecinde yaşanan çatışma konularında kök aile sorunları (\%16,3) ilk sırada yer almaktadır. Kök aile sorunlarından sonra tarafların en çok beyan ettikleri çatışma konusu tehdit-kötü söz-hakaret $(\% 14,3)$ olmuştur. Bu çatışma konularını ekonomik meseleler (\%14,0), sorumsuz davranma $(\% 13,5)$, şiddet $(\% 11,5)$ ve aldatma $(\% 7,9)$ takip etmektedir. Ancak belirtmek gerekir ki, bu çatışma konularının hiçbirisi tek başına boşanma sebebi değildir. Ancak bir arada olduklarında, süreklilik göstererek çatışma eşiğini aştıklarında ve tarafların bu çatışma konularının çözümüne ilişkin inançları yok olduğunda dolayısıyla bir birikim neticesinde boşanma gündemi haline gelmektedirler. Aşağıda yer alan bir duruşmada davalı kadının ablasının beyanı bu durumu örneklendirmektedir.

[35] "Bir olay olmadı, tırmandı tırmandı buralara kadar geldi..." (Dosya no 35, çekişmeli boşanma davası, tahkikat aşaması, davalı kadının ablasının beyanı).

Çalışmada elde edilen yukarıdaki verilerle uyumlu olacak şekilde yapılan diğer araştırmalarda da benzer sonuçların elde edilmiş olduğu görülmektedir. Türkiye boşanma nedenleri araştırmasına (TBNA, 2014) göre en sık rastlanan boşanma nedenleri yakın çevrenin evliliğe müdahalesi (\%40) ile duygusal ilişkidir (\%38). Bu gerekçeleri aldatma (\%35), ekonomik sorunlar (\%34) ve şiddet (\%34) takip etmektedir. Eski eşinin veya kendisinin alışkanlıklar, (\%31), yaşam tarzı (\%25) veya değerleri (\%20) nedeniyle evliliğinin sona erdiğini belirtenlerin oranı da azımsanmayacak düzeydedir. Eşlerden birinin ev içi görev ve sorumlulukları yerine getirmemesi (\%29) veya çocuk bakı- 
miyla yeteri kadar ilgilenmemesi de (\%18) boşanmaya yol açan hususlar arasındadır. Boşanma gerekçeleri arasında öne çıkan diğer gerekçeler cinsel hayat (\%20), çalışma hayatı / işsizlik (\%15), evlilik öncesi eşini yeteri kadar tanımamadir (\%14).

Davaların büyük çoğunluğunda yukarıda bahsedilen çatışma konuları bir arada bulunurken bazı davalarda taraflar arasında çatışma yaşanması için özel bir konuya bile ihtiyaç duyulmadığı ortaya çıkmıştır.

[164] "Evlendiğimizden beri kavga ediyoruz. Havayı bahane eder, suyu bahane eder, bana hakaretler, küfürler eder, misafir kabul etmez. Kızımla, benimle bir yere gelmez, dü̈̆̈̈̈, etkinlik..." (Dosya no 164, çekişmeli boşanma davası, davacı adamın beyani)

Haley, bu durumu kurallarla açıklamaktadır. Haley (1988)'e göre, çözümü en kolay çatışmalar, eşlerin hangi kurallara uymaları gerektiği ile ilişkili olan çatışmalardır. Eşler arasındaki bu tür sorunlar eninde sonunda bir çözüme ulaşır. Ancak, eşler arasındaki anlaşmazlıklar, kuralların kimin tarafından konulması gerektiğinden kaynaklanırsa, bu çatışmaların çözümü diğer çatışmaların çözümünden daha zordur ve eşler arasında şiddetli kavgaların doğmasına yol açar. Kuşkusuz, bir evlilikte temel hak ve özgürlükler temel bir çelişki haline getirilirse, artık bu evlilikte iki filmden hangisinin seyredileceği bile, eşler arasında boşanmaya neden olabilecek kavgalara yol açabilir. Eşler arasındaki çatışmaların diğer bir kaynağı da eşlerin kurallar konusundaki çatışmaları çözebilmek için koydukları kural ötesi (meta rule) kuralların ilişkinin diğer kuralları ile çatışmasıdır.

Haley, evlilikte çatışmaların uygun şekilde yönetilememesine doğru evrilen süreci şu şekilde özetlemiştir. Ona göre, genç çift yeni ilişkilerini olumlu bir şekilde çözerlerken anlaşmazlıklarını çözmek için de farklı yollar bulmak zorundadır. Birlikteliklerinin başında, yeni evliliğin olumlu havası yüzünden ve birbirlerinin duygularını incitmek istemediklerinden açıkça karşı çıkmalardan ya da tehlikeli ifadeler kullanmaktan kaçınırlar. Zamanla kaçındıkları karşı çıkışlar büyümeye başlar ve kendilerini sürekli tartışmanın eşiğinde ve birbirlerine kızarken bulurlar. Bazen konuşulamayan konular evliliğin parçası olur. Bu süreçte anlaşmazlıkları çözmenin ve sorunları halletmenin yolları bulunur. Bazen çözümler başarılı olmaz ve evlilikten kaynaklanan mutsuzluğun büyümesine neden olur (Haley, 2006).

Konuşulamayan konular evliliğin parçası olduğu zaman, bu konular dava dilekçesine yazılacakları güne kadar saklı kalır. Çözüme kavuşturulmayan 
her bir çatışma, evliliğin karanlık tarafında başka bir çatışmanın nedeni olmak üzere yerini alır. Boşanma dilekçesi, evlilik sürecinde halının altına süpürulen konularla doludur. Bir zamanlar birbirlerini seven bu çifti karşılıklı taraf olmaya iten her ne ise, pandoranın kutusunda saklı kalan "o şeyler" in birer ürünüdür. Dolayısıyla evlilik içindeki çatışmalar uygun bir şekilde yönetilmediğinde, biriken ağıtlara dönüşebilir ve bu durum boşanma sürecinin tohumlarının atılmasına yol açabilir.

Çiftler gerçek fiziksel ayrılığa geçtikleri zaman, aile üyeleri arasında yüksek strese ve gerilime neden olan boşanmanın yasal, ekonomik ve velayet paylaşımı konuları ön plana çıkar. Aşağıda boşanma sürecinde taraflar arasında yaşanan çatışma konularına yer verilmiştir.

Tablo 15. Boşanma Sürecinde Çatışma Konuları

\begin{tabular}{lll}
\hline Boşanma Sürecinde Çatışma Konuları & $\mathbf{N}$ & $\mathbf{\%}$ \\
\hline Boşanmayı Kabul Etmeme & 23 & 5,1 \\
\hline Velayet & 69 & 15,0 \\
\hline Nafaka Miktarı & 131 & 29,0 \\
\hline Tazminat Miktarı & 113 & 25,0 \\
\hline Mal Paylaşımı & 52 & 11,5 \\
\hline Çeyiz-Takılar & 36 & 8,0 \\
\hline Kişisel İlişki Tesisi & 18 & 4,0 \\
\hline 6284 Tedbir Kararı & 12 & 2,4 \\
\hline Toplam & 454 & 100,0 \\
\hline
\end{tabular}

Tablo 15, boşanma sürecindeki çatışma konularını ele alır. Veriler mahkeme sürecinde duruşma gözlem yolu ile elde edildiği için çatışma konuları boşanma hukukunun çerçevesi içinde şekillendirilmiştir. Buna göre tarafların üzerinde anlaşamadıkları konuların başında nafaka (\%29,0), tazminat $(\% 25,0)$, mal paylaşımı $(\% 11,5)$, çeyiz ve takılar $(\% 8,0)$ gibi ekonomik konular gelmektedir. Bunu velayet $(\% 15,0)$ ve boşanmayı kabul etmeme $(\% 5,1)$ konuları takip etmektedir. Velayet konusunda çatışma yaşayan taraflardan bir kısmı $(\% 4,0)$ da kişisel ilişki tesisinde de sorun yaşadıklarını bildirmiştir. Kişisel ilişki tesisinde sorun yaşayan taraf ise çoğunlukla babalar olarak gözlemlenmiştir.

Duruşma gözlemleri neticesinde boşanma sürecinde yaşanan çatışma konularının kesişimselliği dikkate değer bir veri olarak ortaya çıkmıştır. Örneğin, ekonomik meseleler velayet konusunu, boşanmayı istememe tedbir kararlarını, kök aile sorunları diğer çatışma konularını etkilemektedir. 
Boşanmaya karar verme insan hayatında yer alan en stresli karar olmayabilir ancak zor alınan kararlardan biridir (Allen ve Hawkins, 2017). Çünkü yaygın bir ifade ile "Kimse boşanmak için evlenmez" ama bazıları boşanır. Boşanmanın evlilik kurumuna zarar vereceğine ilişkin toplumsal bir önyargı vardır. Ancak sonsuza dek devam etmesi gerektiğine inanılan kutsal evlilik algısının evliliğe, boşanmadan daha çok zarar verebileceği çoğunlukla hesaba katilmaz.

Boşanmanın kabul edilemez oluşunun altında pek çok farklı konu olabilir. Toplumsal öğretiler, bireysel koşullar, boşanmanın güçsüzleştirici etkisi, boşanma sonrası hayatın belirsizliği, dul kalma sorunu, korku, depresyon, ruhsal sorunlar, bağımlılık örüntüleri, başarısızlık hissi, ekonomik meseleler, boşanma sonrası yoksullaşma, yarım elma sendromu, terk edilmeye yönelik tepkiler bu örneklerden bazılarıdır.

Ancak iki yakın iç içe yaşamın birbirinden ayrılmasının pratik zorluklarının ötesinde, boşanma önemli bir sembolik boyut içerir: kutsal olana sayg1sızlık etmek. Bilhassa, evliliklerin kalıcı olacağı düşünüldügü için, boşanma, çözülmekte olan ilişkilerin yol açtığı çelişki ile yüzleşmeyi ve bu çelişkiyi çözmeyi içerir (Hopper, 2001). Boşanma kararı aldığında birey toplumsal öğretilerin dışına çikmış olur. Bu sebeple çiftlerden bazıları evli kalmak uğruna halen sorunlu evliliklerine devam etme eğilimi göstermektedir. Günümüzde halen pek çok kadın sadece boşanmak istediği için erkek şiddetine maruz kalmakta hatta öldürülmektedir. Kocaları ile hayatların devam ettirmeme kararı alan kadınlar bu kararlarını hayatları ile ödemek zorunda bırakılmaktadirlar.

Boşanmaya karar verme konusundaki çatışmalar, tarafların diğer çatışma konularında uzlaşmaya varmalarının önündeki en büyük engel olarak ortaya çıkmaktadır. Ancak bazı durumlarda ise tam tersine bir etki söz konusu olabilmektedir. Örneğin boşanma sürecinin çatışma konularının başında gelen ekonomik sorunlar tarafların boşanmama kararlarına etki edebilmektedir. Ancak burada önemle üzerinde durulması gereken konu, ekonomik konuların toplumsal cinsiyet konusu ile ilişkisidir.

Iversen ve Rosenbluth (2010) evlilik ve boşanma kalıplarını bir kadının ekonomik kararlarını belirleyen temel teşvikler olarak tanımlamaktadır. Kadınların maruz kalabileceği iki pazarın evlilik piyasası ve/veya iş piyasası olduğunu savunurlar. Ayrımcı bir işgücü piyasasıyla karşı karşıya kalan ancak aktif bir evlilik piyasası yaşayan kadınlar, becerilerine en büyük getiriyi elde 
etmek için enerjilerini evlilik pazarında yoğunlaştıracaklardır. Bu durumda, erkekler dış işlerde, kadınlar ise ev işlerinde uzmanlaşacaktır (akt: Kercheval ve diğerleri, 2013).

Toplumsal cinsiyete dayalı aile içindeki işbölümüyle toplumsal cinsiyetlendirilmiş roller, birçok kadın ve çocukların mağduriyetine ve avantajsızlıklarına neden olacak şekilde sonuçlanmaktadır. Kurumsal olarak, kadınların çocuklara ve diğer bağımlı aile üyelerine ihtimam göstermeleri beklenmektedir. Bu nedenle kadınların dışarıdaki çalışmaları, erkekler kadar önemli görülmez. Sonuç olarak, kadının erkeğe ekonomik bağımlılığı devam eder. Dolayısıyla, kültürel ve ekonomik anlamda kadınların içinde bulunduğu eşitsiz durum, sosyal yapıyı yeniden üretmektedir (Young, 2001; akt: Uygur, 2015).

Bunun sonucu olarak da kadının kocasının koruyuculuğuna bırakılması gerekmektedir; ayrıca, bir erkeğin cinsel arzularını doyurup yuvaya bakmakla da yükümlüdür. Toplumun kendisine yüklediği bu göreve, kocaya hizmet gözüyle bakılmaktadır. Dolayısıyla koca da ona armağanlar almak, ayrıldıkları zaman dul maaşı vermek, geçimini sağlamak zorundadır. Toplum, kocanın hizmetine verdiği kadına borcunu erkek aracılığıyla ödemektedir. Evli kadının görevlerini yerini getirmekle kazandığı haklar, kocanın zorunlulukları biçiminde dile gelir. Erkek evlilik bağını dilediği zaman koparıp atamaz, bir kadından ayrılmak ya da boşanmak, kamu güçlerinin kararına bağlıdır ve koca kimi zaman bunun için para ödemek zorundadır (Beauvoir, 2010).

Ekonomik meselelerin hukuktaki karşılığı ise nafaka, tazminat ve mal paylaşımında yer alır. Medeni Kanun'un 174. ve 175. maddeleri, tazminat ve nafaka ile ilgilidir. Yasaya göre, mevcut veya beklenen menfaatleri boşanma yüzünden zedelenen kusursuz veya daha az kusurlu taraf, kusurlu taraftan uygun bir maddi tazminat isteyebilir. Boşanmaya sebep olan olaylar yüzünden kişilik hakkı saldirıya uğrayan taraf, kusurlu olan diğer taraftan manevi tazminat olarak uygun miktarda bir para ödenmesini isteyebilir (TMK, m.174). 175. maddeye göre ise, boşanma yüzünden yoksulluğa düşecek taraf, kusuru daha ă̆ır olmamak koşuluyla geçimi için diğger taraftan mali gücü oranında süresiz olarak nafaka isteyebilir. Nafaka yükümlüsünün kusuru aranmaz (TMK, m.175).

Medeni kanunun bu hükmü, boşanmadan sonra yoksulluğa düşecek olan tarafı koruma amacına yönelik olduğu içindir ki, boşanmış olan yoksul tarafa verilecek olan yoksulluk nafakası, hiçbir surette diğer tarafa yükletilen bir ceza veya tazminat niteliğinde değildir (Akıntürk ve Ateş, 2016). Bakım ve 
geçindirme ödevi hukuk uygulayıcılarının özellikle üzerinde durdukları bir konudur. Boşanma süreci devam ederken evliliğin sonlanmamış olması sebebiyle bu ödevlerin yasa gereği devam ediyor oluşu tedbir nafakası uygulamasını kadınların haklı kazanımları olarak nitelendirmektedir.

Her ne kadar yasa cinsiyet ayrımı yapmaksızın her iki eşi kapsıyor olsa da pratik uygulamada durum böyle değildir. Zira bu düzenlemelerde sadece biçimsel eşitlik anlayışından hareket edilerek kadınların dezavantajlı olduğu durumlar görmezden gelindiği için boşanma hukukunda kadınlar erkeklere tabi hale gelebilmektedir (Bartlett, 1999; akt: Karacan, 2018). Dolayısıyla bu durum kadınları nafaka ve tazminat konularının talep edicileri haline getirirken erkekleri de bahşedici rolüne bürümektedir. Bu durum ise kadınları erkeklerin gözünde para avcısı bir konuma sokmaktadır.

Oysa nafaka ve tazminat boşanma sonrası yoksullaşan kadınların en temel haklarından birisidir. Çünkü kadın evliliği seçerek piyasa ile olan ilişkisini bitirmektedir. Kadın için evlilik biricik geçim yolu, varoluşunu doğrulamaya yarayacak biricik toplumsal kurumdur (Beauvoir, 2010). Dolayısıyla evlilik her ne kadar her iki taraf için de taviz vermeyi gerektirse de ancak kadınlar, çoğunlukla ev hanımı oldukları için erkeklerden daha fazla özgürlük ve özerklik kaybederler. Kadınlar, entelektüel ve duygusal kaynaklarını erkeklerden daha fazla eşlerine ve çocuklarına harcarlar. Bir evlilik bozulursa, kadın, ekonomik güvencesini ve maddi faydaların kocasından daha fazla kaybeder (Dempsey, 2002).

Boşanma sürecinde tarafların yaşadıkları çatışma konularından bir diğeri de velayet konusudur. Boşanma kararı veren hâkimin evlilik içinde doğan çocuklarin velayeti ile ilgili düzenleme yapması zorunludur (TMK m.336/3). Dolayısıyla velayet konusu boşanma konusunun doğal bir sonucudur. Davanın kazanma ve kaybetme üzerine kurulu olması tarafları her alanda kazanan olmaya yönlendirebilmektedir. Özellikle evlilik içi çatışmaların hala sıcak kaldığı evliliklerde bu durum daha belirgin bir hal alabilmekte dolayısıyla bireyler karı-koca çatışmasını anne-baba rolü üzerinden değerlendirebilmektedir. Velayet de tıpkı ekonomik meseleler gibi alt metinleri olan bir çatışma konusudur. Velayet gündeme geldiğinde, çoğunlukla gündem aslında sadece velayet değildir. Dikkatli bir gözlem altında başka konuların başka gündemlerin ve başka eğilimlerin olduğu ortaya çıkmaktadır.

Bu durum özellikle kadına yönelik erkek şiddetinde varlık bulmaktadır. Şiddet faili erkeklerin "çocuklarını elinden alırım" tehdidi, kadınların şiddete 
katlanmalarının öncelikli nedenleri arasında yer almaktadır (Akyüz ve diğerleri, 2014). Dolayısıyla boşanmanın sorumluluğu genellikle kadına yüklenir ve çocukların bakımından da ağırlıklı olarak kadınlar sorumlu olmaya devam ederler (Ecevit ve Karkıner, 2011). Çünkü velayet ve kişisel ilişkinin düzenlenmesinde "kadın", toplumsal cinsiyet kalıp yargılarıyla şekillenen "annelik" çerçevesinde, beklendiği gibi bir anne olduğu ölçüde saygı görmektedir (Yücel, 2018).

Bu konu toplumsal bir kabul olarak ele alınmaktadır. Örneğin Çarkoğlu ve Kalaycıoğlu tarafından 2013 yılında yapılan bir araştırmaya göre, deneklerin yarısı kadarı (\%48) çalışan bir annenin çalışmayan bir anne kadar çocuğuna yakın ve güven dolu bir ilişki geliştiremeyeceğini, yüzde kırk kadarı (\%39) geliştirebileceğini belirtmiştir. Deneklerin yarıdan fazlası (\%58) da okul öncesi yaştaki bir çocuğun annesinin çalışmasının çocuğu kötü bir biçimde etkilemesini olası gördüğünü ifade etmiştir. Deneklerin sadece dörtte biri kadarı (\%24) okul öncesi yaştaki bir çocuğun annesinin çalışmasının çocuğu kötü bir biçimde etkilemesini olası olarak görmediğini belirtmiştir (Çarkoğlu ve Kalaycıŏ̆lu, 2013).

Velayetin ebeveynlerden birine verilmesi, diğer ebeveyn ile kişisel ilişki kurulması anlamına gelir. Yukarıda yer alan araştırma verilerinden ve duruşma gözlemlerinden anlaşıldığı üzere velayet çoğunlukla anneye verilmektedir. Velayetin anneye verilmesi babayı kişisel ilişki tesisi ile karşı karşıya getirmektedir.

Velayet kendisinde olmayan tarafın, mahkemece belirlenen zaman dilimlerinde çocukla görüşebilmesi olgusuna genel olarak çocukla kişisel ilişki kurulması denilmektedir. Velayet hakkı kendisinde olan taraf, kararda belirlenen zaman dilimlerinde, çocuğu diğer tarafla görüştürmekle yükümlüdür (Koçyıldırım, 2010).

Tablo 15'e göre, 18 birey çocuğu ile kişisel ilişki kuramamasını sorun olarak gündeme getirilmiştir. Çocuğu ile kişisel ilişki kurma noktasında sorun yaşayan bireylerin 2 tanesi kadın, 16'sı ise erkektir. Duruşmalardan birinde, hâkim huzurunda çocuk dinlenilmesi esnasında yukarıda yer alan "çocukla kişisel ilişki tesisi" gündeme gelmiştir. Müşterek çocuk velayet değişikliğinde annesinin yanında kalmak istediğini ancak bu durumun babası ile olan ilişkisini olumsuz anlamda etkilediğinden bahsetmiştir. 
[170] "Annemle babam boşandiklarmda velayetim babama verildi. Babamla 3-4 sene yaşadım. Babamla yaşarken bir sorunum yoktu. Babamin maddi durumu kötüydü. Benim büyük büyük hedeflerim vardl, hemşire olmak gibi. Annemle telefonla konuşurken gel biraz da bende kal dedi. Babam da gidersen bir daha gelme dedi. Ondan beri babamla hiç görüşüyoruz." (Dosya no 170, velayet davası, müşterek çocuğun [lise öğrencisi] beyanı).

Yukarıda verilen vakadan da anlaşılacağı üzere, boşanma sürecinde kişisel ilişki tesisi hassasiyetle ele alınması gereken bir konudur. Çünkü boşanmanın değişimi gerektiren bir özelliğe sahip olması neticesinde boşanma ile birlikte çocuğun hayatında da pek çok alanda değişiklik gündeme gelmektedir. Çocuğun bu değişime adapte olması, sürecin çocuk dostu bir şekilde yönetilmesi ile ilişkilidir.

Ancak, bir evliliği sona erdirmenin kargaşası çoğu zaman ebeveynlerin duygusal kaynaklarını tüketir ve verebilecekleri bakımın kalitesini engeller. Boşanma sonrasında, bazı bekâr ebeveynler çocuklarının ihtiyaçlarına daha az yanıt verir, çocuklarını daha az etkili bir şekilde izler ve daha sert bir disiplini dağıtır. Buna bağlı olarak, velayet kendisinde olmayan ebeveyn (genellikle babalar) çocuklarının yaşamlarına daha az karışır. Bu, özellikle ebeveyn yeni bir ailenin sorumluluğunu üstlenmişse geçerlidir. Birçok genç yetişkin, babalarıyla temaslarını kaybetmenin, ebeveynlerinin boşanmasının en üzücü yönü olduğunu bildirmektedir (Amato ve Boyd, 2014).

\section{Tartışma ve Sonuç}

Bu çalışmada boşanma sürecindeki çiftlerin içinde bulundukları durum boşanmanın yasal boyutu çerçevesinde duruşma gözlemleri ile ele alınmıştır. Bu kapsamda taraflarm davact-davalı olma durumu, cinsiyet, avukatla temsil, aile yaşam döngüsü, müşterek çocuk, ikamet yeri ve ayrlma biçimleri gibi taraflara ilişkin demografik bulgular, davanın nev'i, dosyanın aşaması, karara bağlanması, velayet kararı gibi davaya ilişkin bulgular, duruşmaya katılma durumu, duruşma salonunda çatışma yaşanma durumu gibi duruşmalara ilişkin bulgular ve son olarak da evlilik ve boşanma sürecindeki çatışma konularma ilişkin bulgular incelenmiştir.

Bu çalışmaya göre, boşanma davalarında daha çok kadınlar davacı olmaktadır. Hukuksal bir kişiliğe sahip olmak, en genel ifadesiyle, haklara ve yüküm- 
lülüklere sahip bir özne olmak demektir (Işıktaç ve Koloş, 2017). Dolayısıyla kadınların çoğunlukla davacı olmaları onları davalarını ispat etme noktasında yükümlü kılmaktadır. Hukukun ispat yükümlülüğü, kadınların haklarını savunabilmeleri için avukatla temsil edilmelerini gerekli kılmaktadır.

Araştırmaya göre kadınların yarısından fazlası avukat ile temsil edilirken, erkeklerin daha azı avukat ile temsil edilmektedir. Oysa boşanma davalarında avukatla temsil hak kayıplarını önüne geçilmesi açısından önemlidir. Çünkü tarafların avukatla temsil edilememesi onların boşanmadan doğan haklara ve özellikle mahkemeye başvurma hakkına erişimin önünde bir engel teşkil edebilmektedir.

Mahkemeye başvurma hakkı ya da mahkemeye başvurma hakkının bir görünümü olan mahkemeye ulaşma hakkı hukukun üstünlüğünün dolay1sıyla hukuk devletinin sağlanması için en önemli haklardan biridir. Nitekim Anayasamızın 36. maddesi "Herkes, meşru vasıta ve yollardan faydalanmak suretiyle yargı mercileri önünde davacı ve davah olarak iddia ve savunma... hakkma sahiptir." diyerek hak arama özgürlüğünü düzenlemiştir (İnceoğlu, 2009).

Duruşma gözlemlerinden elde edilen verilere göre, boşanmalar evliliklerin ilk yıllarında gündeme gelebildiği gibi azımsanmayacak ölçüde evliliğin ilerleyen dönemlerinde de gündeme gelebilmektedir. Ancak boşanmanın evliliğin daha da ilerleyen yıllarında gerçekleşme olasılığı ise oldukça azdır. Dolayısıyla boşanma yaşlılık döneminin gündemi olmaktan uzaktır.

Bir diğer araştırma verisi tarafların yarısının çocuğa sahip olmasıdır. Çocukların büyük bir kısmı 18 yaş altındadır. Dolayısıyla boşanma sürecinin aktörleri yalnızca taraflar değildir. Bu sebeple boşanma çalışmalarında boşanmanın çocuk yanının da üzerinde durulması gerekmektedir. Bu durum boşanma sürecindeki çatışma konularından biri olan velayeti gündeme getirmektedir. Dolayısıyla boşanmaya karar verilen davalardan bir kısmında velayet konusunda da karar verilmiştir. Velayet kararları incelendiğinde ise velayetin yüksek bir oranla anneye verildiği görülmektedir.

Kadınların yarıya yakını bu süreci kök ailelerin yanında atlatırken, erkeklerin kadınlara oranla daha büyük bir kısmı aile konutunda kalmaya devam etmektedirler. Tarafların yarısından fazlası, taraflardan birinin evden ayrılması ile fiziksel ayrılığı deneyimlerken bunu taraflardan birinin kök ailesini çağırması izlemektedir. Daha az kısımda ise tarafların fiziksel ayrılıkları devlet kontrolünde gerçekleşmiş ve erkek uzaklaştırma kararı almıştır. Kadınların bu süreci daha çok kök ailelerin yanında atlatmaları kadınların ekonomik 
bağımsızlıklarının erkeklere oranla düşük olması ve çocuk bakımını erkeklere oranla daha çok üstlenmeleri ile ilişkili olabilmektedir. Dolayısıyla özellikle bu süreçte kadınların iş ve çocuk bakımı konusunda devlet eli ile desteklenmesi kadınların süreci daha sağlıklı bir şekilde atlatabilmeleri açısından önemlidir.

Kadınların büyük bir kısmı duruşmalara katılırken erkeklerin yarıdan biraz fazlası duruşmalara katılım göstermiştir. Erkekler ve kadınlar davanın ilk aşaması olan ön inceleme aşamasına katılım noktasında çekingen davranırken tahkikat aşamasına daha fazla katılım göstermektedir; ancak katılımın yoğun olduğu aşama, davanın hükme bağlandığı sözlü yargılama aşamasıdır. Duruşmaya katılan bir diğer grup ise ailenin daha geniş üyelerinden oluşmaktadır. Kök aile üyeleri özellikle bu grup içerisinde daha fazla duruşmalara katılan gruptur. Kuzen, arkadaş ve diğer aile yakınları duruşmayı takip eden diğer izleyicilerdir. Duruşma salonunda taraflar arasında yaşanan çatışmaların büyük bir kısmı tanık beyanlarının dinlenmesi sebebiyle tahkikat aşamasında gerçekleşmiştir. Davaların büyük bir kısmı çekişmeli boşanma davalarından, daha azı anlaşmalı boşanma davalarından oluşmaktadır. Duruşmaların çoğunluğu tahkikat aşamasındadır.

Tarafların evlilikleri içerisinde farklı konularda ve zamanlarda çatısma içinde oldukları ortaya çıkmıştır. Bu konular duruşmalarda dile getirilen sıklığa göre sırasıyla: kök aileler; kötü söz, hakaret ve tehdit; ekonomik meseleler; sorumsuz davranma; kadına yönelik erkek şiddeti; aldatma; başkalarının yanında aşağılama; cinsel sorunlar; ruhsal sorunlar; özel günleri birlikte kutlamama; misafir istememe; evlilik ilişkisi içerisinde erkeğin başka birinden çocuğunun olması; üvey çocuklardır.

Evlilik ilişkisi içerisinde en çok dile getirilen çatışma konusu kök ailelerdir. Tarafların ve tanıkların beyanları, kök ailelerin evliliklerin merkezinde yer aldığına ve çoğu çatışmanın birebir sebebi olurken, birebir sebebi olmadıkları çatışmalarda da dolaylı yoldan katkılarının olduğuna yönelik aktarımları kök aile konusunu evlilik çatışmalarının başlıca gündemi haline getirmektedir.

Elde edilen bir diğer önemli bilgi, çatışma konularının müstakil olmadıklarıdır. Bir çatışma konusu tek başına varlık göstermemektedir. Özellikle ekonomik meseleler, cinsiyet temelli ev içi iş bölümü ile ve bu iki konu ev içi şiddet ile yakından ilgili görünmektedir. Kötü söz, hakaret ve tehdit de şiddetle bağlantılı olan bir diğer çatışma konusudur. Şiddetin farklı boyutları, şidde- 
tin bütün çatışma konuları ile temas içinde olmasına neden olmaktadır. Ancak şiddetle ilgili öne çıkan bir diğer veri, genellikle şiddetin tanığının olmamasıdır. Şiddet, gözlerden uzak, kapalı kapılar ardında sergilenmektedir. Bu sebeple şiddetin başlıca tanıkları genellikle sadece çocuklardır. Oysa çocuklar için şiddete tanık olmak şiddete maruz kalmakla eş değerdir.

Taraflar boşanmanın yasal boyutuna geçtiklerinde ise ilk karşılaştıkları çatışma konusu belki de boşanmaya karar verme noktasında gerçekleşmektedir. Duruşma gözlemlerinden elde edilen verilere göre bazen çiftler bu kararı ortak alırken çoğunlukla boşanma sürecini başlatan eşlerden biridir. Diğer eş ise bu karara tepki olarak ya "beni istemeyeni ben hiç istemem" diyerek karşıllk vermekte ya da boşanmamak konusunda israr edebilmektedir. Yine de bu ısrarın sebebi her zaman evliliği sürdürme isteği ile ilişkili olmayabilir. Boşanma kararına ilişkin tarafların evliliklerinden aynı anda vazgeçememeleri, diğer çatışma konularında uzlaşmalarının önündeki en büyük engeldir.

Boşanma, bireylerin yaşam stilleri üzerinde köklü değişikliklere neden olmaktadır. Örneğin boşanma ile mekân, bütçe, sosyal ağlar, ebeveynlik sistemlerinde köklü değişiklikler meydana gelmektedir. Bu gündemler ise başlı başına çatışma kaynakları olabilir. Duruşma gözlemlerinden elde edilen verilere göre boşanma sürecinde yer alan bu gündemler en çok kadınları etkilemektedir. Çünkü, boşanma gündeme geldiği zaman aile konutunu terk eden, boşanma ile yoksulluğa düşen, tek ebeveynliği deneyimleyen ve yeniden kimlik geliştirmek, toplum içinde sosyal ağlarda değişiklikler yapmak zorunda olan kesim genellikle kadınlardır. Dolayısıyla boşanmanın kadın ve erkek arasında gerçekleşen ancak çoğunlukla erkek yararına işleyen bir kurum olduğu söylenebilir.

Boşanma sürecinde tarafların en çok çatışma içinde oldukları konular; nafaka, tazminat, alacak-verecek konularıdır. Genellikle bu çatışma konuları içinde büyük hesaplaşmaları barındırmaktadır. Ayrıca boşanmanın yasal boyutu ve mahkeme süreci bu büyük hesaplaşmanın daha yoğun bir şekilde yaşanmasına zemin hazırlamaktadır.

Bir davanın tarafı olmak çiftleri belirgin bir şekilde çatışma ortamına sokmaktadır. Bu çatışma ortamında ise kazanma ve kaybetme arasındaki sınır oldukça belirgindir. Boşanma davasının kaybedilmesi aynı zamanda evlilik içerisindeki "kusurlu eşi" ilan etmek anlamı taşıdığından bu durum tarafları bir zamanlar evli oldukları ve özellikle müşterek çocuklarının olması duru- 
munda bundan sonra da ilişkilerinin devam edeceği gerçeğinden uzaklaştırmaktadır. Dolayısıyla boşanma davalarında "kusura dayanma ilkesi" boşanma davalarında var olan çatışmayı artırıcı bir etkiye sahip gibi görünmektedir.

Boşanmalarda, tek bir boşanma nedeninden bahsetmek zordur. Boşanma nedeni, bir konudan ziyade evlilik ilişkisi içinde yaşanan çatışma konularının çözüme kavuşturulamaması ile ilgilidir. Yani insanlar geçim sıkıntısı çektikleri, aldatıldıkları, şiddete maruz kaldıkları, kök aile sorunları ile uğraştıkları için boşanmamakta bu sorunların üstesinden gelemedikleri ve evliliklerinin ilerleyen yıllarında da gelemeyeceklerine inandıkları için boşanıyor görünmektedirler.

Sonuç olarak evlilik sürecinde yaşanan çatışmaların uygun bir şekilde yönetilmesi iki açıdan oldukça önemlidir. Birincisi bu durum evliliklerin sağlıklı bir hale getirilmesine etki edebilir. İkincisi ise evlilik sürecinde yaşanan çatışmaların boşanma sürecindeki çatışma konularını etkilemesi durumu ile bağlantılı olarak evlilik sürecindeki çatışma konularının uygun bir şekilde ele alınması, tarafların bu süreci barışçıl bir şekilde geçirmelerine olanak sağlayabilir. 


\title{
EXTENDED ABSTRACT
}

\section{Divorce Parties Adam And Eve: A Trial Observation Research}

\author{
Hatice Nuhoğlu- Filiz Demiröz \\ Kastamonu University
}

Divorce has a long history; it goes back to the very first written documents. Every civilization reorganized divorce according to the specific conditions in its era. Although the concept has a long history, it has been only recently legally accepted. However, there are still some cases when divorce is not considered legal in some societies.

The legal dimension of divorce is regulated by the Civil Law. Rules of divorce and separation are specifically determined in the related articles of the law. When the actual legal process of the divorce starts, these specific rules cause the 'things' that were once ignored as problems during the marital relationship to turn into treasures hidden under pillows; the conflicts experienced during marriages are used as weapons in the battle of divorce. They become the arsenals to be used against the enemy, the instruments that will determine the winner at the end of the process; therefore, the concept of divorce gains a new dimension during the court process. To separate their ways, couples that decide to divorce have to demonstrate these experiences "here and now", in the courtroom, in front of "the strangers".

The important point that was specifically analyzed in this study, which involves trial observation in family courts, is that the process of following a case for observation in courtrooms is not a common procedure. While trial observation has become globally common in recent years, the observation in family courts dealing with the trials about domestic relations hasn't yet reached the same level; this is why researches about observing divorce cases are quite a few. As this study has been prepared according to the data obtained from divorce case observations, it has a pioneering role in the field.

This study is prepared to reveal the untold divorce stories behind courtrooms; this is why the parties of divorce cases are described and their figurations in courtrooms are presented. The method of this research is quantitative and the data of the research were collected through a structured (systemic) 
observation method, which is one of the qualitative data collection methods. A total of 200 trials in 11 family courts in Ankara Sihhiye Court were carefully observed in the data collection process and the obtained data were analyzed in SPSS 23.0 for Windows Program. The descriptive statistics in the research were: Frequency (\%) for categorical variables, mean \pm standard deviation for constant variables and minimum-maximum.

Findings were collected in 4 basic sub-titles: (1) Data about the divorce parties (2) Data about the case (3) Data about the trial (4) Data about the issues of conflict. In this context, the analyzed demographic findings of the parties were: The state of being compliant-defendant, gender, being represented by an attorney, family life cycle, and child in common, place of residence, and type of separation. In addition to these, the findings of the case such as the action of the trial, stage of the case, settling the case, and determining the custody were analyzed. Findings of the hearings such as attending a trial, having a conflict in the courtroom and findings of the issues of conflict in the process of marriage and divorce were also carefully analyzed in the scope of the research study.

According to this study, women attend more as prosecutors in divorce cases. Research results indicate that more of half of the women are represented by a lawyer in divorce cases while fewer men are represented by a lawyer. According to the data obtained from trial observations, divorces may appear in the first few years of marriages; on the other hand, it should also be mentioned that there are a considerable number of divorces in older marriages. Another research data indicate that half of the couples have children. Most of these children are under the age of 18 . While almost half of the women overcome this problematic period with their family (origin family), the number of men who continue to stay in the house is higher when compared to women. More than half of the parties experience physical separation when a partner leaves the house; on the other hand, it was determined that the origin family of a partner invite him/her to their house in case of a divorce process. A smaller group of couples experienced physical separation under the control of the state forces and women claimed restraint order against men. While most of the women individually attended the trial, slightly more than half of the men attended their divorce trial. While both men and women behaved timidly during the preliminary examination, which is the first stage of the trial, they participated more in the process of inquiry. However, the highest participation 
was the oral proceeding state, which is the stage of announcing final judgment.

It was revealed that the parties experienced conflicts on different issues at different times. These issues (lined according to the statement frequency) are origin family of the couple, bad language, insults, and threats, financial problems, irresponsibility, male violence against female, infidelity, humiliation in society, sexual problems, mental problems, not celebrating special days together, not inviting any guests, a husband having a child from someone else during the marriage, stepchild. A piece of significant information obtained in the research was that the issues of conflict weren't self-contained; in other words, issues were related to one another. Financial problems and separation of housework according to gender seems to be especially related to domestic violence. Bad language, insults, and threats are also related to violence. As violence has different dimensions, it is connected to all of the issues of conflict. However, significant data about violence show that generally, violent acts have no witness. Individuals use violence behind closed doors when there is no one to see; this is why most of the primary witnesses of these acts are children. It should be noted that when a child witnesses a violent act, he/she deeply feels as if he/she is the physical victim of it.

The most frequently experienced problems during the divorce process are; alimony, indemnity and receivables and payables. These issues of conflict generally involve big acts of revenge, reckonings. On the other hand, the legal dimension of divorce and the process of trial lay the basis of intense experiences about these big acts of revenge. Generally, it is difficult to mention a single reason for divorce. Rather than a single issue, the grounds for divorce are about the inability to find solutions to the issues of conflict in a marital relationship. Namely, people don't simply get a divorce as they have financial problems, they are cheated or subjected to violence; people seem to claim divorce when they see that they cannot overcome problems and when they believe that won't be able to overcome in the future.

\section{Kaynakça / References}

Adalet Bakanlığı. (2015). Adalet Bakanlığı Stratejik Planı 2015-2019. https://www.adalet.gov.tr/Bakanlik/StratejikPlan/Stratejik-Plan-20152019.pdf 
Akıntürk, T. ve Ateş, D. (2016). Türk medeni hukuku: Aile hukuku ikinci cilt. İstanbul: Beta Yayınları.

Allen, S. ve Hawkins, A. J. (2017). Theorizing the decision-making process for divorce or reconciliation. Journal of Family Theory \& Review 9, 50-68.

Amato, P. R. ve Boyd, L. M. (2014). Children and divorce in world perspective. Contemporary ussues in family studies: Global perspectives on partnerships, parenting and support in a changing world (içinde). Ed:Angela Abela and Janet Walker. John Wiley \& Sons, Ltd. Published.

Arıkan, Ç. (1996). Halkın boşanmaya ilişkin tutumları araştırması. Başbakanlık Aile Araştırma Kurumu. Bilim Serisi 96. Ankara.

Avrupa Konseyi Toplumsal Cinsiyet Eşitliği Stratejisi 2014-2017. http://ailetoplum.aile.gov.tr/uygulamalar/aile-danismanligi

Aybay, A., Aybay, R. ve Pehlivan, A. (2018). Hukuka giriş. İstanbul: İstanbul Bilgi Üniversitesi Yayınları.

Baitar, R., Buysse, A., Brondeel, R., Mol, J. ve Rober, P. (2012). Toward High-Quality Divorce Aggrements: The Influence of Facilitative Professionals. Negotation Journal, 28(4), 453-473.

Beauvoir, S. (2010). Kadın "İkinci Cins" evlilik çă̆ı. İstanbul: Payel Yayınevi.

Blackman, L. (2017). Insan hakları aktivistleri için dava izleme rehberi. (Ayşegül Bahçıvan Çev.). İstanbul: Eşit Haklar İçin İzleme Derneği.

Clarke-Stewart, A. ve Brentano, C. (2006). Divorce causes and consequences. Yale University Press: United States of America.

Cloke, K. ve Goldsmith, J. (2018). Çatışma yönetimi. İstanbul: Sola Unitas Yayınları. Coontz, S. (2006). The origins of modern divorce. Family Process, 46(1).

Çakır, S. (2012).Türkiye'de evli kadınlar ekseninde evlilik/aile algısı ve boşanma olgusu. Hukuk Felsefesi ve Sosyolojisi Arkivi (içinde). 26. Kitap.İstanbul Barosu.

Çarkoğlu, A. ve Kalaycıoğlu, E. (2013). Türkiye' de aile, iş ve toplumsal cinsiyet. İstanbul Politikalar Merkezi (IIPM). http://ipc.sabanciuniv.edu/publication/turkiyede-aile-is-ve-toplumsal-cinsiyet/ Erişim tarihi: 21.02.2019.

Çiftçioğlu, K. (2017). Dava izlemenin tarihsel gelişimi ve dünya deneyimleri. dava izleme: Duruşma salonunda devlet ve yurttaş. İstanbul: Mas Matbaacılık.

Dempsey, K. (2002). Who gets the best deal from marriage: Women or men?. Journal of Sociology. The Australian Sociological Association, 38 (2), 91-110.

Dinç, G. (2005). Avrupa insan hakları sözleşmesi'ne göre silahların eşitliği. TBB Dergisi, 57, 283-306.

Dönmez, A., Büyükşahin, A., Taluy, N., Başer, I. ve Güler, M. (2009). Yakın ilişkiler psikolojisi. Ankara: Nobel Yayın. 
Ecevit, Y. ve Karkıner, N. (2011). Aile ve evlilik. Toplumsal cinsiyet sosyolojisi (içinde). Eskişehir: Anadolu Üniversitesi Yayınları.

Elveriş, İ., Jahic, G. ve Kalem, S. (2009). İstanbul asliye hukuk mahkemelerinde yargılama süreci. İstanbul: İstanbul Bilgi Üniversitesi Yayınları.

Gençcan, Ö. (2016). Boşanma usul hukuku. Ankara: Yetkin Yayıncılık.

Haley, J. (1988). İletişim: Psikolojik sorunlar ve psikoterapi. (Ali Uzunöz Çev.). Ankara: Çark Kitabevi Yayınları.

Haley, J. (2006). Sıradışı terapi: Milton H. Erickson'un psikiyatrik teknikleri. İstanbul: Yol Yayınları.

Hopper, J. (2001). The symbolic origins of conflict in divorce. Journal of Marriage and Family, 63, 430-445.

Hukuk Muhakemeleri Kanunu. (2011, 4 Şubat). Resmi Gazete (Sayı: 27836). Erişim adresi: https://www.mevzuat.gov.tr/MevzuatMetin/1.5.6100.pdf

Işıktaç, Y. ve Koloş, U. (2017). Hukuk sosyolojisi. İstanbul: İstanbul Bilgi Üniversitesi Yayınları.

İnceoğlu, S. (2009). Hukuk devleti ilkesi bakımından adliye gözlemleri ve adalet barometresi araştırmaları. Adalet gözet: Yargı sistemi üzerine bir inceleme (içinde). Ed. Seda Kalem. İstanbul: İstanbul Bilgi Üniversitesi Yayınları.

Karacan, O. (2008). Catherina Mackinnon'un görüşleri çerçevesinde boşanma nedenleri bakımından hukukta cinsel tahakkum. (Yüksek Lisans Tezi). Ankara Üniversitesi, Ankara.

Kercheral, J., Markowitz, D., Monson, K. ve Read, B. (2013). Research on barriers to employment and decent work for women. International Labour Organization.

Koçyıldırım, G. (2010). Sosyal hizmet bakış açısıyla çocuk teslimine ve çocukla kişisel ilişki kurulmasına dair ilamların icrası uygulamaları. Yüksek Lisans Tezi. Ankara: Hacettepe Üniversitesi Sosyal Bilimler Enstitüsü. Sosyal Hizmet Anabilim Dalı.

Kurt Konca, N. (2014). Medeni usul hukukunda aleniyet ilkesinin sinırlandirılması. Süleyman Demirel Üniversitesi Hukuk Fakültesi Dergisi (Sdühfd) Mihbir Özel Sayısı, 4(2), 65-96.

Özgüven, İ. E. (2010). Ailede iletişim ve yaşam. Ankara: PDREM Yayın.

Salts, C. J. ve Smith, J. A. (2013). Special topics in family therapy. Lorna L. Hecker and Joseph L. Wetchler (Ed.). An introduction to marriage and family therapy içinde (s.449-478). New York: Routledge.

Sencer, M. ve Sencer, Y. (1978). Toplumsal araştırmalarda yöntembilim. Ankara: TODAİE. 
Soysal, D. (2016). Beauvoir dersleri "Evli Kadın" ve "Anne" üzerine bir deneme. İstanbul: Belge Yayınları.

Türkiye Boşanma Nedenleri Araştırması-TBNA. (2014). Erişim Tarihi: 20.02.2017. http://ailetop-

lum.aile.gov.tr/data/54292ce0369dc32358ee2a46/tbna2014_kitap.pdf

TÜİK (2016). Evlenme ve boşanma istatistikleri. Erişim tarihi: 12.08.2017.

TÜİK (2018). Evlenme ve boşanma istatistikleri. Erişim tarihi: 07.09.2019.

Türk Medeni Kanunu. (2001, 8 Aralık). Resmî Gazete (Sayı: 24607). Erişim adresi: https://www.mevzuat.gov.tr/MevzuatMetin/1.5.4721.pdf

Uygur, G. (2015). Toplumsal cinsiyet ve adalet: Hukuk adaletsizdir. Ankara Barosu Dergisi, 4, 121-132.

Yavan, D. (2017). Cezasızlıkla mücadelede bir yöntem olarak dava izleme nedir?. Dava İleme: Duruşma Salonunda Devlet ve Yurttaş. İstanbul: Mas Matbaacilik.

Yücel, Ö. (2018). Medeni hukuk açısından toplumsal cinsiyet. Şiddet ve Ayrımcılık. Hukuk ve Toplumsal Cinsiyet Çalışmaları içinde. Ankara: Seçkin Yayıncılık. Zastrow, C. ve Kirst-Ashman, K. (2015). İnsan davranışı ve sosyal çevre II. (D. B. Çiftçi. Çev.). Ankara: Nika Yayınları.

\section{Kaynakça Bilgisi / Citation Information}

Nuhoğlu, H. ve Demiröz, F.(2020). Boşanmanın tarafları Ademler ve Havvalar: Bir duruşma gözlem araştırması. OPUS-Uluslararası Toplum Araştırmaları Dergisi, 15(25), 3710-3752. DOI: 10.26466/opus.656948 